\title{
Characterization of the N-linked oligosaccharides from human chorionic gonadotropin expressed in the methylotrophic yeast Pichia pastoris
}

\author{
Véronique Blanchard • Rupali A. Gadkari • Gerrit J. Gerwig • \\ Bas R. Leeflang • Rajan R. Dighe • Johannis P. Kamerling
}

Published online: 5 December 2006

(C) Springer Science + Business Media, LLC 2006

\begin{abstract}
Human chorionic gonadotropin (hCG) is a heterodimeric, placental glycoprotein hormone involved in the maintenance of the corpus luteum during the first trimester of pregnancy. Biologically active hCG has been successfully expressed in the yeast Pichia pastoris (phCG). In the context of structural studies and therapeutic applications of phCG, detailed information about its glycosylation pattern is a prerequisite. To this end N-glycans were released with peptide- $N^{4}$ - $(N$-acetyl- $\beta$-glucosaminyl)asparagine amidase $\mathrm{F}$ and fractionated via anion-exchange chromatography (Resource Q) yielding both neutral (80\%) and charged, phosphate-containing (20\%) high-mannosetype structures. Subfractionations were carried out via normal phase (Lichrosorb- $\mathrm{NH}_{2}$ ) and high-pH anion-exchange (CarboPac PA-1) chromatography. Structural analyses of the released $\mathrm{N}$-glycans were carried out by using HPLC profiling of fluorescent 2-aminobenzamide derivatives, MALDI-TOF mass spectrometry, and $500-\mathrm{MHz}$ ${ }^{1} \mathrm{H}-\mathrm{NMR}$ spectroscopy. Detailed neutral oligosaccharide structures, in the range of $\mathrm{Man}_{8} \mathrm{GlcNAc}_{2}$ to $\mathrm{Man}_{11} \mathrm{GlcNAc}_{2}$ including molecular isomers, could be established, and structures up to $\mathrm{Man}_{15} \mathrm{GlcNAc}_{2}$ were indicated. Phosphatecontaining oligosaccharides ranged from $\mathrm{Man}_{9} \mathrm{PGlcNAc}_{2}$
\end{abstract}

V. Blanchard · G. J. Gerwig • B. R. Leeflang · J. P. Kamerling $(\bowtie)$ Bijvoet Center, Department of Bio-Organic Chemistry,

Utrecht University, Padualaan 8,

NL-3584 CH Utrecht, The Netherlands

e-mail: j.p.kamerling@chem.uu.nl

R. A. Gadkari · R. R. Dighe

Department of Molecular Reproduction,

Development and Genetics, Indian Institute of Science,

Bangalore 560012, India to $\mathrm{Man}_{13} P \mathrm{GlcNAc}_{2}$. Mannosyl O-glycans were not detected. Profiling studies carried out on different production batches showed that the oligosaccharide structures are similar, but their relative amounts varied with the culturing media.

Keywords Glycosylation · Pichia pastoris $\cdot$ Human chorionic gonadotropin · High-mannose-type N-glycans . Phosphorylation
Abbreviations
hCG human chorionic gonadotropin
phCG human chorionic gonadotropin expressed in Pichia pastoris
uhCG urinary human chorionic gonadotropin
PNGase F peptide- $N^{4}$-( $N$-acetyl- $\beta$-glucosaminyl)
asparagine amidase $\mathrm{F}$
FPLC fast protein liquid chromatography
2AB 2-aminobenzamide
MALDI-TOF- matrix-assisted laser desorption ionization MS time-of-flight mass spectrometry
HPLC high-performance liquid chromatography
HPAEC high-pH anion-exchange chromatography
PAD pulsed amperometric detection
TOCSY total correlation spectroscopy
ROESY rotating-frame nuclear Overhauser enhance- ment spectroscopy
WEFT water eliminated Fourier transform
MLEV composite pulse devised by M. Levitt

\section{Introduction}

The placental glycoprotein hormone human chorionic gonadotropin (hCG), excreted in the urine, plays a major 
role during the first trimester of pregnancy. It indirectly stimulates the corpus luteum to produce progesterone until the placenta itself acquires the ability to produce this pregnancy-sustaining steroid [1]. Usually, hCG isolated from the urine of pregnant women is used in the in vitro fertilization technology as a therapeutic analogue of lutropin for the induction of final follicular maturation and ovulation in infertile women.

Native hCG consists of two non-covalently associated subunits, denoted $\alpha$ and $\beta$, and is glycosylated for about $30 \%$. The $\alpha$-subunit $(\sim 15 \mathrm{kDa})$, containing 92 amino acids, is $\mathrm{N}$-glycosylated at Asn52 and Asn78, and the $\beta$-subunit $(\sim 23 \mathrm{kDa})$, consisting of 145 amino acids, is N-glycosylated at Asn13 and Asn30 and O-glycosylated at Ser121, Ser127, Ser132, and Ser138. The distribution of the Nglycans on urinary hCG was found to be site-specific [2-4]: monosialylated monoantennary and disialylated diantennary structures, with Neu5Ac in $(\alpha 2-3)$ linkage to Gal, were found at all $\mathrm{N}$-glycosylation sites whereas monosialylated hybrid-type structures only occur at $\alpha$-hCG Asn52 and ( $\alpha 1-6)$-fucosylation only at $\beta$-hCG Asn13 and Asn30. Indications for the occurrence of trisialylated tri- and tri'antennary glycans on $\beta$-hCG have also been reported [5]. Structural data for the O-glycosylation comprise mainly the conventional mono- and disialylated core 1-type structures, the disialyl-hexasaccharide (including core 2 type), and the sialylated disaccharide [6-8]. A random distribution of these O-glycans among the attachment sites has been suggested [9]. Over the years many studies have appeared demonstrating the crucial importance of the glycosylation of hCG for its biological functioning (for a review, see e.g., [10]). In reaching conclusions, site-directed mutagenesis of specific (glycosylation) sites in urinary hCG applying different host cell systems played a major role.

In order to replace for pharmaceutical applications the urinary glycohormone by a recombinant variant, detailed attention has to be paid to the glycosylation patterns generated in relevant host cell systems. Expression of hCG in CHO cells shows the same mono-, di-, tri-, and tri'antennary $\mathrm{N}$-glycans as found for urinary hCG; Neu5Ac occurs in $(\alpha 2-3)$ linkage to Gal. The O-glycans comprise mainly the convential saccharides (see above) $[8,11,12]$. $\mathrm{CHO}$ cells have also been used for generating ${ }^{13} \mathrm{C} /{ }^{15} \mathrm{~N}$ labeled hCG for NMR studies [13]. Expression of hCG in baculovirus insect cell systems yields hCG which appears to have also oligomannose-type chains [14-16]. Furthermore, oligomannose-type chains were found on hCG expressed in Dictyostelium discoideum $[17,18]$. Expression of hCG in malignant trophoblastic JAR cells yielded a $\beta$ subunit with predominantly endo-H-resistant $\mathrm{N}$-glycans and an $\alpha$-subunit with a more complicated array of endo- $\mathrm{H}-$ resistant and endo-H-sensitive (hybrid) $\mathrm{N}$-glycans [19, 20]. Recombinant hCG from mouse C127 mammary tumor cells showed that, compared with urinary hCG, only the $\alpha$ subunit has strongly deviating glycans; i.e., sialylated diantennary chains were suggested to be replaced by notspecified sialylated triantennary chains [21].

In earlier studies it has been shown that the methylotrophic yeast Pichia pastoris allows an easy production of biologically active hCG $[22,23]$. However, P. pastoris does not produce the typical oligomannose-, hybrid- and complex-type glycosylation patterns as generally found in mammalian cell systems. Several studies on other recombinant glycoproteins expressed in P. pastoris have shown that relatively small (compared with glycoproteins from other yeast species) (phosphorylated) high-mannose-type structures are present, generally containing 8 to 14 Man residues [24-28]. O-Mannosylation of proteins expressed in $P$. pastoris has also been reported (1-5 mannose residues) [29-32]; however, it occurs less frequently than $\mathrm{N}$-glycosylation.

In the context of broader studies focused on the pharmaceutical use of $P$. pastoris expressed hCG (phCG) and on the use of $P$. pastoris cells to prepare ${ }^{13} \mathrm{C} /{ }^{15} \mathrm{~N}$-labeled phCG for three-dimensional studies of its structure in solution using NMR spectroscopy, a detailed glycan analysis of phCG was undertaken by mass spectrometry and NMR spectroscopy. In addition, attention was paid to possible changes in glycosylation pattern when changing the culturing conditions.

\section{Materials and methods}

Recombinant hCG expressed in Pichia pastoris (phCG)

The cloning, expression, and purification of biologically active phCG have been described previously [23]. Briefly, PCR-amplified hCG was cloned into a pPIC9k expression vector, and the best phCG-secreting clone was selected and grown in a 10 liter fermenter vessel. The secreted protein was purified from the culture supernatant and its biological activity determined by RIA. Batch I was produced exactly according to [23]; ammonia was used as nitrogen source, and glycerol then methanol as carbon sources. Batch II was produced using FM22 medium (Invitrogen); ammonium sulfate was used as nitrogen source, and glycerol then methanol as carbon sources (to be published).

\section{Monosaccharide analysis}

Human phCG $(400 \mu \mathrm{g})$ was desalted on a Pharmacia FPLC system using 5 HiTrap columns $(5 \times 5 \mathrm{ml})$ connected in series. The eluent consisted of $5 \mathrm{mM} \mathrm{NH} \mathrm{NCO}_{3}$ and the fractionation was monitored by UV detection at $214 \mathrm{~nm}$. The sample was lyophilized, and subjected to methanolysis 
(1.0 M methanolic $\mathrm{HCl}, 24 \mathrm{~h}, 85^{\circ} \mathrm{C}$ ) followed by re$N$-acetylation and trimethylsilylation [33]. The generated mixture of trimethylsilylated methyl glycosides was analyzed by GLC on an EC-1 column $(30 \mathrm{~m} \times 0.32 \mathrm{~mm}$; Alltech, Breda, The Netherlands), using a Chrompack CP9002 gas chromatograph (temperature program $140-240^{\circ} \mathrm{C}$ at $4^{\circ} \mathrm{C} / \mathrm{min}$ ) and flame-ionization detection.

\section{Reduction and carboxymethylation}

Human phCG was reduced and $S$-carboxymethylated according to procedures described before [21]. Briefly, phCG (12 mg) was dissolved in $6.5 \mathrm{ml} 1 \mathrm{M}$ Tris/ $\mathrm{HCl}, \mathrm{pH} 8.25$, containing $6 \mathrm{M}$ guanidinium- $\mathrm{HCl}, 1 \mathrm{mM}$ EDTA, and $34 \mathrm{mM}$ dithiothreitol; and the solution was kept for $2 \mathrm{~h}$ at $37^{\circ} \mathrm{C}$. Then, iodoacetic acid $(0.5 \mathrm{M}$ in $0.5 \mathrm{M} \mathrm{NaOH})$ was added to a final concentration of $68 \mathrm{mM}$, and the incubation was continued for $30 \mathrm{~min}$ in the darkness. After quenching the reaction by adding an excess of 2-mercaptoethanol, low-molecular-mass compounds were removed by using $5-\mathrm{kDa}$ centrifugal concentrators, and the retentate was lyophilized. The chemical conversion was checked by $10 \%$ SDS-PAGE under reducing conditions.

Separation of the subunits

For the N-glycan profiling studies on the $\alpha$ - and $\beta$-subunits of the phCG batches I and II, prior to digestion with peptide- $N^{4}$ - $(N$-acetyl- $\beta$-glucosaminyl)asparagine amidase $\mathrm{F}$ (PNGase F; EC 3.5.1.52) (Roche Molecular Biochemicals, IN) and labeling with 2-aminobenzamide (2AB; Sigma), reduced and carboxymethylated phCG (2 mg) was separated into subunits on a Superdex G75 column $(60 \times 2.6 \mathrm{~cm}$; Pharmacia, Uppsala, Sweden) using $50 \mathrm{mM} \mathrm{NH} \mathrm{NHCO}_{3}$, $\mathrm{pH} 7.0$, as eluent at a flow rate of $1 \mathrm{ml} / \mathrm{min}$, monitored at $214 \mathrm{~nm}$ (Uvicord, LKB).

Release and isolation of N-glycans

Reduced and carboxymethylated phCG (batch I; 12 mg) was dissolved in $6 \mathrm{ml} 20 \mathrm{mM} \mathrm{NaH}{ }_{2} \mathrm{PO}_{4} / \mathrm{Na}_{2} \mathrm{HPO}_{4}, \mathrm{pH} 7.2$, containing $10 \mathrm{mM}$ EDTA, and digested with $8 \mathrm{U}$ of PNGase $\mathrm{F}$ for $24 \mathrm{~h}$ at $37^{\circ} \mathrm{C}$. The $\mathrm{N}$-glycan pool was separated from the protein on a Superdex G75 column using the same conditions as described above. N-Deglycosylated phCG and the pool of N-glycans were then lyophilized.

\section{FPLC fractionation}

The pool of N-glycans was fractionated according to charge on a Resource $\mathrm{Q}$ anion-exchange column (1 ml, Pharmacia) at a flow rate of $1 \mathrm{ml} / \mathrm{min}$ [6] using a Pharmacia FPLC system. The elution, monitored by UV absorbance at
$214 \mathrm{~nm}$, was performed with $4 \mathrm{ml} \mathrm{H}_{2} \mathrm{O}$, followed by a linear concentration gradient of $0-500 \mathrm{mM} \mathrm{NaCl}$ in $9 \mathrm{ml}$ $\mathrm{H}_{2} \mathrm{O}$. The fractions obtained were desalted on Carbograph extract-clean columns (Alltech) [34], and lyophilized.

HPLC fractionation

The FPLC fractions were further fractionated on a Lichrosorb- $\mathrm{NH}_{2} 10 \mu \mathrm{m}$ column $(25 \times 0.46 \mathrm{~cm}$, Alltech $)$ equipped with a LiChrospher Amino $5 \mu \mathrm{m}$ guard column $(7.5 \times$ $4.6 \mathrm{~mm}$ ), using a Waters $600 \mathrm{HPLC}$ system. Elutions were performed with a linear gradient of $30 \mathrm{mM} \mathrm{K} \mathrm{KPO}_{4} /$ $\mathrm{KH}_{2} \mathrm{PO}_{4}, \mathrm{pH} 6.8$, in acetonitrile at a flow rate of $1 \mathrm{ml} / \mathrm{min}$, and monitored by UV absorbance at $206 \mathrm{~nm}$. Relevant fractions were concentrated under a $\mathrm{N}_{2}$ stream, desalted on Carbograph extract-clean columns (Alltech), and lyophilized.

\section{HPAEC fractionation}

HPAEC was performed on a Dionex DX 500 system equipped with a pulsed amperometric detection (PAD) unit. Neutral oligosaccharide fractions were subfractionated on a CarboPac PA-1 column $(4 \times 250 \mathrm{~mm})$ using a gradient of $0.5 \mathrm{M}$ sodium acetate/ $0.1 \mathrm{M} \mathrm{NaOH}$ (solvent $\mathrm{B}$ ) in $0.1 \mathrm{M}$ $\mathrm{NaOH}$ (solvent $\mathrm{A}$ ) at a flow rate of $1 \mathrm{ml} / \mathrm{min}$. The samples were loaded in $2 \% \mathrm{~B}-98 \% \mathrm{~A}$, then the proportion of $\mathrm{B}$ was increased to $15 \%$ in $15 \mathrm{~min}$, and then to $20 \%$ in $17 \mathrm{~min}, 33 \%$ in $6 \mathrm{~min}, 100 \%$ in $2 \mathrm{~min}$. After $5 \mathrm{~min}$ of isocratic elution, the solvent system was put back to the initial conditions and equilibrated for $10 \mathrm{~min}$. Fractions were immediately neutralized with $0.1 \mathrm{M} \mathrm{HCl}$, desalted on Carbograph extractclean columns (Alltech), and lyophilized.

Modifications of the charged N-glycans

Mild acid treatment of glycans $(1 \mu \mathrm{g})$ was carried out in $100 \mathrm{mM} \mathrm{HCl}(500 \mu \mathrm{l})$ for $30 \mathrm{~min}$ at $100^{\circ} \mathrm{C}$ [35]. Terminal phosphate groups attached to non-reducing ends of glycans were cleaved by treatment with $2 \mathrm{U}$ alkaline phosphatase (Sigma, St. Louis, MO) in $50 \mathrm{mM}$ citrate/phosphate buffer, $\mathrm{pH} 9$, for $24 \mathrm{~h}$ at $37^{\circ} \mathrm{C}$.

\section{AB-labeling of N-glycans and HPLC profiling}

2AB-labeling of oligosaccharides was performed as described earlier [36, 37]. Briefly, about $1 \mathrm{nmol}$ of dried glycans was incubated with $0.35 \mathrm{M}$ 2-aminobenzamide/1 M sodium cyanoborohydride in acetic acid-dimethyl sulfoxide $(3: 7, \mathrm{v} / \mathrm{v})$ $(10 \mu \mathrm{l})$ for $2 \mathrm{~h}$ at $65^{\circ} \mathrm{C}$. For the clean-up of the $2 \mathrm{AB}$-labeled glycans, pre-treated $(0.5 \%$ acetic acid for $24 \mathrm{~h})$ quartz microfibre filters (QM-A, Whatman, England) were used. After applying the samples to a paper strip, the excess of reagents was removed by washing with $8 \times 0.5 \mathrm{ml}$ acetonitrile. 
Glycans were eluted from the paper strip with $4 \times 0.5 \mathrm{ml} \mathrm{H}_{2} \mathrm{O}$, and, after lyophilization, residues were dissolved in $200 \mu \mathrm{l}$ $\mathrm{H}_{2} \mathrm{O}$.

Neutral $\mathrm{N}$-glycan profiling was conducted by HPLC on a normal phase TSKgel Amide- 80 column $(4.6 \times 250 \mathrm{~mm}$; Tosoh BioScience, Germany), using a Waters 2690 XE Alliance System, equipped with a Waters 474 scanning fluorescence detector $\left(\lambda_{\text {exc } \cdot \max }=373 \mathrm{~nm}, \lambda_{\text {em } \cdot \max }=420 \mathrm{~nm}\right)$. For the elution, two solvent systems were used: solvent $\mathrm{A}$, $50 \mathrm{mM}$ ammonium formate, $\mathrm{pH}$ 4.4-acetonitrile $(1: 4, \mathrm{v} / \mathrm{v})$; solvent $\mathrm{B}, 50 \mathrm{mM}$ ammonium formate, $\mathrm{pH}$ 4.4. The linear gradients were comprised of 6.5 to $43.8 \%$ B in $100 \mathrm{~min}$, followed by 43.8 to $100 \%$ B over the next $3 \mathrm{~min}$, then $100 \%$ $\mathrm{B}$ for $5 \mathrm{~min}$ before returning to the initial conditions in $5 \mathrm{~min}$. The total run time at a flow rate of $0.8 \mathrm{ml} / \mathrm{min}$ was 140 min. Elution positions of the 2AB-labeled glycans were standardized in glucose units $(\mathrm{GU})$ using a $2 \mathrm{AB}$-labeled partial dextran hydrolysate as reference $[38,39]$.

Charged N-glycan profiling was performed by HPLC on a weak anion-exchange Vydac 301 VHP5410 column (4.6× $100 \mathrm{~mm}$; Grace Vydac, Hesperia, CA), using the same equipment as above. For the elution, two solvent systems were used: solvent A, $20 \%$ acetonitrile; solvent $\mathrm{B}, 0.5 \mathrm{M}$ ammonium formate, $\mathrm{pH} 4.4-\mathrm{H}_{2} \mathrm{O}$-acetonitrile $(5: 3: 2, \mathrm{v} / \mathrm{v})$. After running $100 \%$ A for 5 min, charged $\mathrm{N}$-glycans were eluted with a linear gradient of 0 to $100 \%$ B over $35 \mathrm{~min}$. $100 \% \mathrm{~B}$ was maintained for $5 \mathrm{~min}$ before returning to the initial conditions in $1 \mathrm{~min}$ followed by a reequilibration step of $14 \mathrm{~min}$. The total run time at a flow rate of $0.4 \mathrm{ml} / \mathrm{min}$ was $60 \mathrm{~min}$.

Matrix-assisted laser desorption ionization time-of-flight mass spectrometry

MALDI-TOF mass spectra were recorded on a Voyager-DE mass spectrometer (Applied Biosystems) with implemented delayed extraction technique, equipped with a $\mathrm{N}_{2}$ laser (337 nm, $3 \mathrm{~ns}$ pulse width). Spectra were recorded in a linear mode at an accelerating voltage of $24.5 \mathrm{kV}$ using an extraction delay of $90 \mathrm{~ns}$. For measurements in the positiveion mode, $0.5-\mu 1$ samples were mixed in a $1: 1$ ratio on the target with 2,5-dihydroxybenzoic acid $(10 \mathrm{mg} / \mathrm{ml})$ dissolved in $\mathrm{H}_{2} \mathrm{O}$-ethanol $(9: 1, \mathrm{v} / \mathrm{v})$. For measurements in the negative-ion mode, $2^{\prime}, 4^{\prime}, 6^{\prime}$-trihydroxyacetophenone $(10 \mathrm{mg} / \mathrm{ml})$ dissolved in acetonitrile $-20 \mathrm{mM}$ ammonium citrate $(1: 1, \mathrm{v} / \mathrm{v})$ was used as a matrix. In this case, the samples were dried under reduced pressure [40].

\section{${ }^{1}$ H-NMR spectroscopy}

${ }^{1} \mathrm{H}-\mathrm{NMR}$ spectra were recorded on a Bruker AMX-500 spectrometer (Bijvoet Center, Department of NMR Spectroscopy, Utrecht University) at a probe temperature of $27^{\circ} \mathrm{C}$ and $\mathrm{p}^{2} \mathrm{H}$ 7. Samples were dissolved in $500 \mu 199.9 \%{ }^{2} \mathrm{H}_{2} \mathrm{O}$ (Cambridge Isotope Laboratories Inc., Andover, MA). Chemical shifts $(\delta)$ are expressed in ppm by reference to internal acetone $\left(\delta 2.225\right.$ in $\left.{ }^{2} \mathrm{H}_{2} \mathrm{O}\right)$ [41]. HOD signal suppression was performed by applying a WEFT pulse sequence in 1D experiments [42] and by a pre-saturation of $1 \mathrm{~s}$ during the relaxation delay in 2D experiments. 2D-TOCSY spectra were recorded using MLEV-17 mixing sequence cycles of $50 \mathrm{~ms}$, 2D-ROESY spectra were recorded with a mixing time of $300 \mathrm{~ms}$, and 2D-NOESY spectra with a mixing time of $500 \mathrm{~ms}$. NMR data sets were processed using in house developed software packages (J.A. van Kuik, Bijvoet Center, Department of Bio-Organic Chemistry, Utrecht University).

\section{Results}

Monosaccharide analysis [33] of phCG revealed a carbohydrate content of $30 \%$ (by mass) and the presence of mannose and $N$-acetylglucosamine in the molar ratio of 9:2. After reduction and carboxymethylation, phCG was digested with PNGase F, whereby SDS-PAGE was used to check the completeness of the de-N-glycosylation. The released pool of $\mathrm{N}$-glycans, isolated via size-exclusion chromatography on Superdex G75, was fractionated by anion-exchange chromatography on Resource Q (FPLC), yielding three carbohydrate-containing fractions eluting at positions corresponding to neutral $(\mathbf{Q 0} ; 80 \%)$ and charged (Q1; 15\% /Q2; 5\%) compounds (Fig. 1), as calculated from UV peak areas.

Neutral oligosaccharides

The pool of neutral N-glycans Q0 was analyzed in terms of molecular mass by MALDI-TOF-MS. In Fig. 2a its

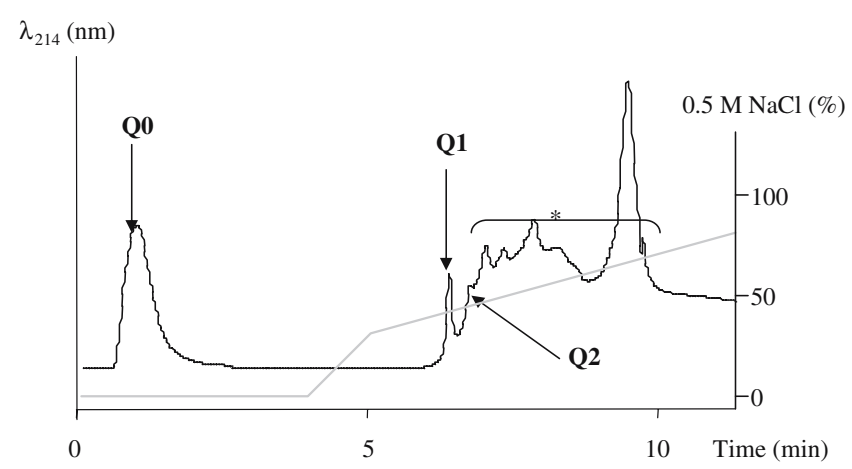

Fig. 1 Fractionation pattern of PNGase F-released phCG N-glycans at $214 \mathrm{~nm}$ on a FPLC Resource Q anion-exchange column. Elutions were performed at a flow rate of $1 \mathrm{ml} / \mathrm{min}$ with a gradient of $\mathrm{NaCl}$ in $\mathrm{H}_{2} \mathrm{O}$ as shown in the figure. The fraction marked by an asterisk did not contain any carbohydrate material 
Fig. 2 MALDI-TOF mass spectra: (a) neutral fraction Q0, positive-ion mode, $[\mathrm{M}+\mathrm{Na}]^{+}$; (b) charged fraction $\mathbf{Q 1}$, negative-ion mode, $[\mathrm{M}-\mathrm{H}]^{-}$. $\mathrm{M}=\mathrm{Man} ; \mathrm{GN}=\mathrm{GlcNAc}$; $P=$ phosphate
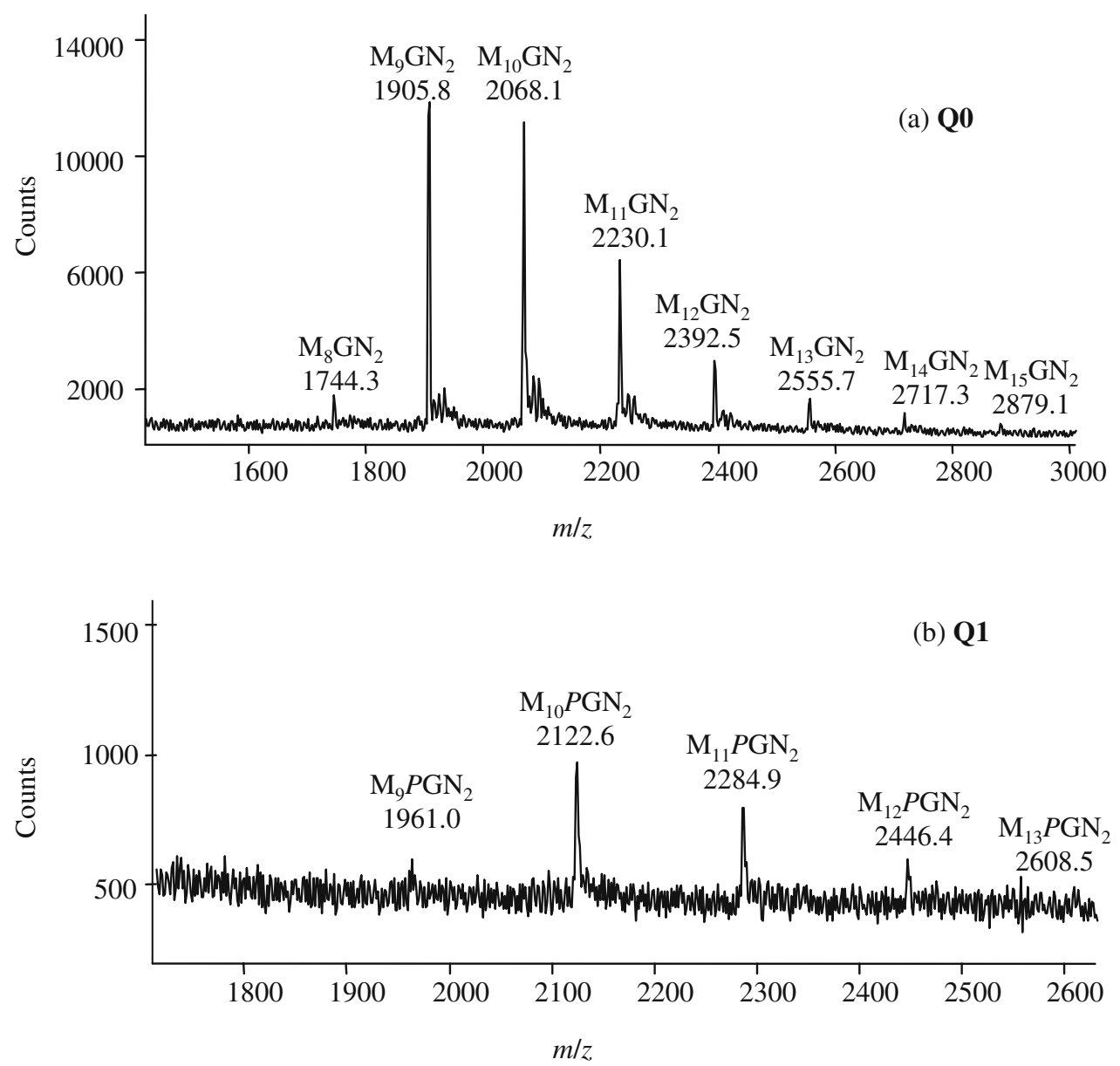

positive-ion mode mass spectrum is depicted, showing that the compounds range from $\mathrm{Man}_{8} \mathrm{GlcNAc}_{2}$ to $\mathrm{Man}_{15}$ $\mathrm{GlcNAc}_{2}$ (Q0.M8 to Q0.M15). The HPLC profile (normal phase TSKgel Amide-80) of the pool of N-glycans Q0, labeled with 2-aminobenzamide ( $2 \mathrm{AB}$ derivatives), is in agreement with the presence of $\mathrm{Man}_{8} \mathrm{GlcNAc}_{2}$ to $\mathrm{Man}_{12}$ $\mathrm{GlcNAc}_{2}$ (Fig. 3). The presence of various structural isomers of the higher mass components (see below) can be held responsible for the not-well resolved HPLC pattern from $\mathrm{Man}_{10} \mathrm{GlcNAc}_{2}$ on. Fractionation of FPLC fraction Q0 by normal-phase HPLC on Lichrosorb- $\mathrm{NH}_{2}$ yielded five subfractions (Fig. 4a), which were analyzed by MALDI-TOFMS to show that in terms of molecular mass pure $\mathrm{Man}_{8} \mathrm{GlcNAc}_{2}$ (11\%), $\mathrm{Man}_{9} \mathrm{GlcNAc}_{2}$ (47\%), Man 10 GlcNAc $_{2}$ (28\%), Man ${ }_{11}$ GlcNAc $_{2}$ (10\%), and Man ${ }_{12}$ GlcNAc $_{2}$ (4\%) oligosaccharides were obtained. The $\mathrm{Man}_{8} \mathrm{GlcNAc}_{2}$ to Man $_{12}$ GlcNAc $_{2}$ subfractions (Q0.M8-Q0.M12) were further investigated by $500-\mathrm{MHz} 1 \mathrm{D}$ and $2 \mathrm{D}{ }^{1} \mathrm{H}-\mathrm{NMR}$ spectroscopy. When necessary, additional fractionations were carried out with HPAEC-PAD on CarboPac PA-1. A summary of the established structures is presented in Scheme 1. The ${ }^{1} \mathrm{H}-$ chemical shifts of the H-1 and H-2 protons of the constituent monosaccharides of the reported structures are listed in
Table 1. The ${ }^{1} \mathrm{H}-\mathrm{NMR}$ data of $\operatorname{Man}_{\mathrm{x}} \operatorname{GlcNAc}_{1}(\mathrm{x}=9-11)$ $[25,43]$ were partly used to assign the N-glycans of phCG.

$\mathrm{Man}_{8} \mathrm{GlcNAc}_{2}$ pool

The structural-reporter-group region of the ${ }^{1} \mathrm{H}-\mathrm{NMR}$ spectrum of subfraction Q0.M8 indicated a homogeneous

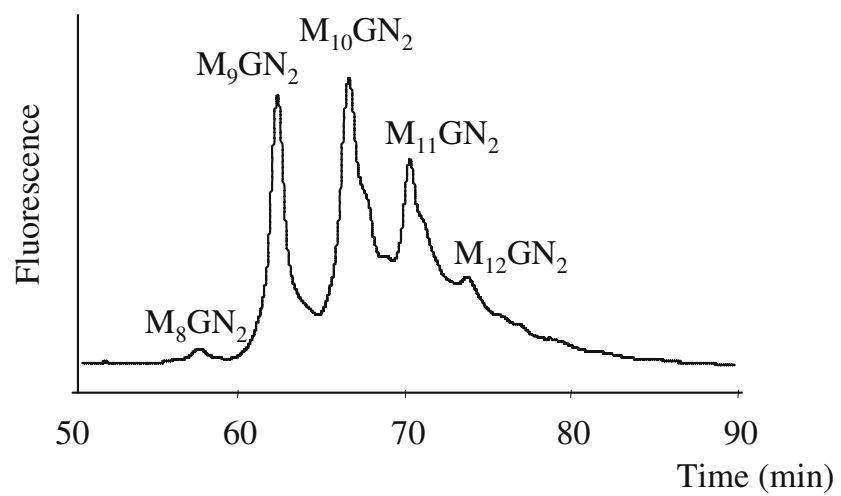

Fig. 3 HPLC profile of the fluorescent 2AB-labeled neutral oligosaccharide pool Q0 on a normal-phase TSKgel Amide-80 column. Elutions were carried out at a flow rate of $0.8 \mathrm{ml} / \mathrm{min}$ with a gradient of ammonium formate, $\mathrm{pH} 4.4$, in acetonitrile (see Materials and methods). $\mathrm{M}=\mathrm{Man}$; $\mathrm{GN}=\mathrm{GlcNAc}$ 
Fig. 4 HPLC elution profile at $206 \mathrm{~nm}$ on Lichrosorb- $\mathrm{NH}_{2}$ of (a) fraction $\mathbf{Q 0}$ and (b) fraction Q1. Elutions were performed at a flow rate of $1 \mathrm{ml} / \mathrm{min}$ with a linear gradient of $30 \mathrm{mM}$ phosphate buffer, pH 6.8, in acetonitrile. $\mathrm{M}=\mathrm{Man}$; $\mathrm{GN}=\mathrm{GlcNAc}$ (a) Q0
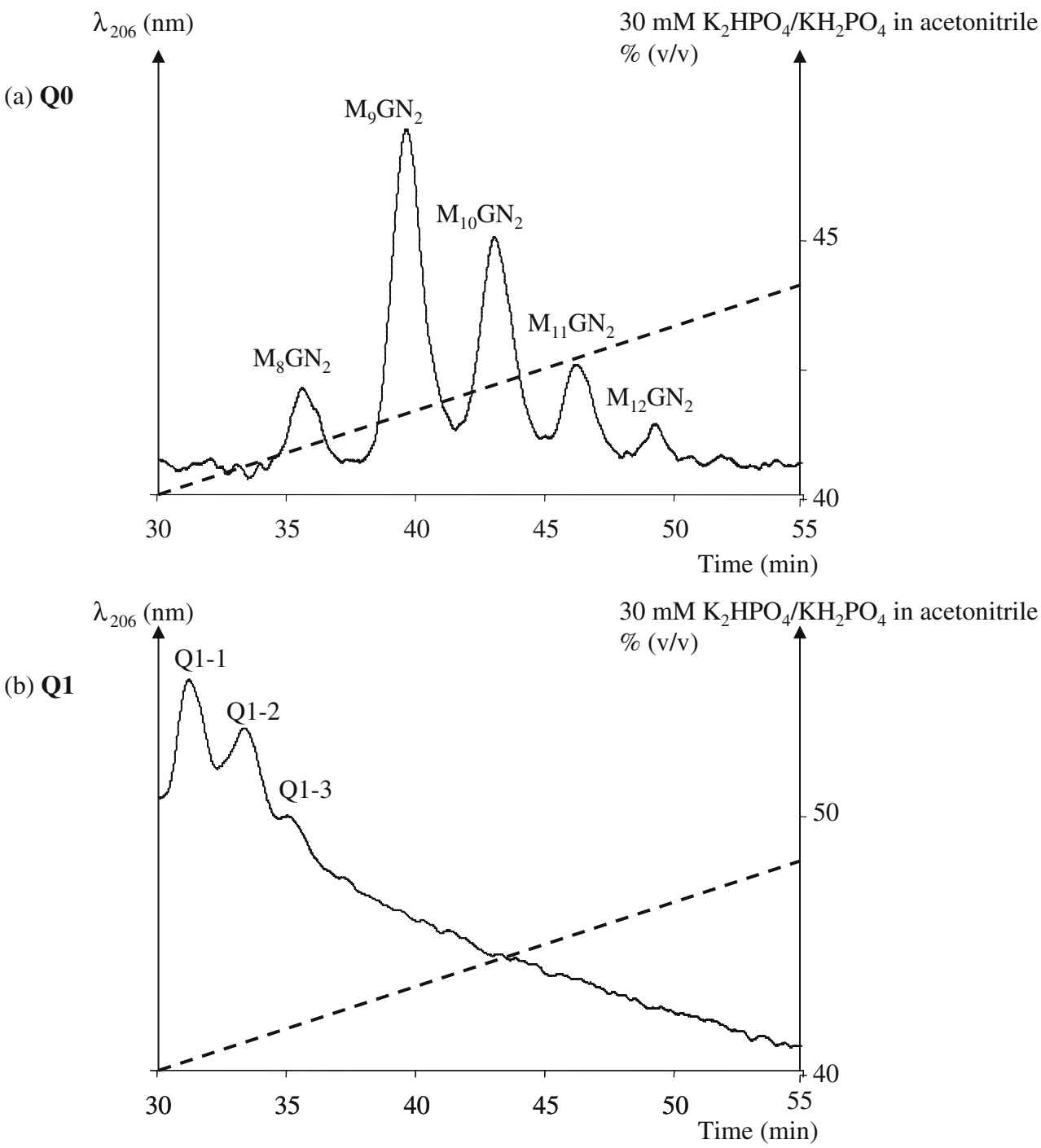

$\mathrm{Man}_{8} \mathrm{GlcNAc}_{2}$ isomer, missing the Man-D2 residue (Fig. 5a, Scheme 1, Table 1). The Man H-1 and H-2 chemical shifts are in agreement with literature data for this structure (see e.g., glycan QN2.4 of the human epidermal growth factor receptor [37]). For comparison with ${ }^{1} \mathrm{H}-\mathrm{NMR}$ data of the isomers missing the Man- $\mathbf{D}_{\mathbf{1}}$ or Man- $\mathbf{D}_{\mathbf{3}}$ residue, see [44] and [45], respectively. For comparison with ${ }^{1} \mathrm{H}$ NMR data of Man $_{9}$ GlcNAc $_{2}$, containing Man-D , Man-D, and Man- $\mathbf{D}_{\mathbf{3}}$, see [46]. The identified isomer, reflecting the usual first steps in trimming $\mathrm{Glc}_{3} \mathrm{Man}_{9} \mathrm{GlcNAc}_{2}$ of $\mathrm{N}$ glycans, has been reported to be an essential intermediate in yeast oligosaccharide processing [27, 47].

\section{$\mathrm{Man}_{9} \mathrm{GlcNAc}_{2}$ pool}

The structural-reporter-group region of the ${ }^{1} \mathrm{H}-\mathrm{NMR}$ spectrum of subfraction Q0.M9 revealed the presence of two Man ${ }_{9} \mathrm{GlcNAc}_{2}$ isomers, Q0.M9-1 and Q0.M9-2, with Q0.
M9-1 as the major component (Fig. 5b, Scheme 1, Table 1). The structure of Q0.M9-1 was identified as an extension of the $\mathrm{Man}_{8} \mathrm{GlcNAc}_{2}$ structure with a Man-C' residue, ( $\alpha 1-6)$-linked with Man-4, thereby creating the typical yeast-processed $\mathrm{Man}_{9} \mathrm{GlcNAc}_{2}$ structure. Compared with the ${ }^{1} \mathrm{H}-\mathrm{NMR}$ spectrum of Q0.M8, the spectrum of Q0. M9 shows two additional structural-reporter-group signals, an $\mathrm{H}-1$ signal at $\delta 4.927$ and an $\mathrm{H}-2$ signal at $\delta 3.99$, both characteristic of terminal Man- $\mathbf{C}^{\prime}$ in a Man- $\mathbf{C}^{\prime}-(\alpha 1-6)-$ Man-4 element [25, 43]. Going from Q0.M8 to Q0.M9-1, shifts are observed for Man-A H-1 ( $\delta 5.088$ vs 5.099) and Man-3 H-2 ( $\delta 4.23$ vs 4.16). Interestingly, the Man-D $\mathbf{D}_{\mathbf{1}}$ and Man-D $\mathbf{3}$ H-1 signals are split, and it is suggested that, due to the extension of $\mathrm{Man}_{8} \mathrm{GlcNAc}_{2}$ with Man-C', Man-D $\mathbf{D}_{\mathbf{1}} \mathrm{H}-1$ shifts a little bit. By integration of the spectrum, it was concluded that this isomer represents about $95 \%$ of the total $\mathrm{Man}_{9} \mathrm{GlcNAc}_{2}$ pool. The low-intense $\mathrm{H}-1$ signal $(5 \%)$ at $\delta 5.404$, representing a Man-A residue extended with a Man- $\mathbf{D}_{2}$ residue, and the 
Man-3 H-2 signal (5\%) at $\delta 4.23$ [41, 46, 48], support the presence of structure Q0.M9-2, the convential precursor $\mathrm{Man}_{9} \mathrm{GlcNAc}_{2}$ structure formed in the oligosaccharide processing of $\mathrm{Glc}_{3} \mathrm{Man}_{9} \mathrm{GlCNAc}_{2}$.

$\mathrm{Man}_{10} \mathrm{GlcNAc}_{2}$ pool

The structural-reporter-group region of the ${ }^{1} \mathrm{H}-\mathrm{NMR}$ spectrum of subfraction Q0.M10 indicated the presence of a mixture of $\mathrm{Man}_{10} \mathrm{GlcNAc}_{2}$ isomers (Fig. 5c, Scheme 1, Table 1). For Man-A two H-1 signals were found: a very minor one corresponding with a Man-A residue bearing a Man- $\mathbf{D}_{\mathbf{2}}-(\alpha 1-2)$ residue $(\mathrm{H}-1, \delta 5.404)$, and a major one reflecting a terminal Man-A residue ( $\mathrm{H}-1, \delta$ 5.100). As a consequence, the very minor $\mathrm{Man}_{10} \mathrm{GlcNAc}_{2}$ isomer is an extension of Q0.M9-2 (not assigned), and the major $\mathrm{Man}_{10} \mathrm{GlcNAc}_{2}$ isomers are extensions of Q0.M9-1, which

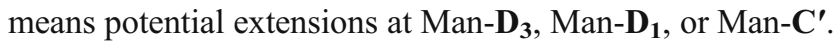
$\operatorname{Man}(\alpha 1-3)$ extensions at Man-D $\mathbf{D}_{\mathbf{1}}$ and Man-D, $\mathbf{D}_{\mathbf{3}}$, as reported for yeast glycans from Saccharomyces cerevisiae (see compounds $\mathrm{M}_{11}$ and $\mathrm{M}_{13}$ in [49]) could be eliminated by inspection of 2D TOCSY spectra of Q0.M10: no H-1,H-2 correlation was found at $\delta 5.144 / 4.23$. This finding is in accordance with the deficiency of the $\alpha-1,3-$ mannosyl- transferase responsible for outer ( $\alpha 1-3)$-mannosylations in $P$. pastoris as compared to $S$. cerevisiae [25]. Comparing the ${ }^{1} \mathrm{H}-\mathrm{NMR}$ spectra of Q0.M9 and Q0.M10 shows various changes in intensities of H-1 signals and new H-1 signals are observed at $\delta 4.912$ and 5.121.

The $\mathrm{Man}_{10} \mathrm{GlcNAc}_{2}$ pool was further fractionated by HPAEC (Fig. 6a), and three subfractions were isolated, Q0. M10-1, Q0.M10-2, and Q0.M10-3, which were checked by MALDI-TOF-MS to be pure $\mathrm{Man}_{10} \mathrm{GlcNAc}_{2}$ isomers. Subfraction Q0.M10-3 did not contain sufficient material for NMR analysis.

The ${ }^{1} \mathrm{H}-\mathrm{NMR}$ spectrum of HPAEC subfraction Q0.M101 revealed the presence of two isomeric structures, compounds Q0.M10-1a and Q0.M10-1b (Fig. 7a, Scheme 1, Table 1), in agreement with the HPAEC peak pattern (Fig. 6a). The relatively high intensities of the structuralreporter-group $\mathrm{H}-1$ signals at $\delta 5.303$ [internal Man unit in Man-( $\alpha 1-2)-M a n-(\alpha 1-$ element] and 5.049 [terminal Man unit in Man-( $\alpha 1-2)$-Man- $(\alpha 1$ - element] indicated that the $\mathrm{Man}_{10} \mathrm{GlcNAc}_{2}$ isomers have the structure Q0.M9-1 with an extra ( $\alpha 1-2)$-linked Man residue. The unusual low intensity of the Man-B H-1 signal ( $\delta 5.144)$ might be due to a change in local mobility of this proton. The H-1 signal at $\delta 5.121$ was assigned to Man- $\mathbf{C}^{\prime}$ when substituted with
Q0.M8

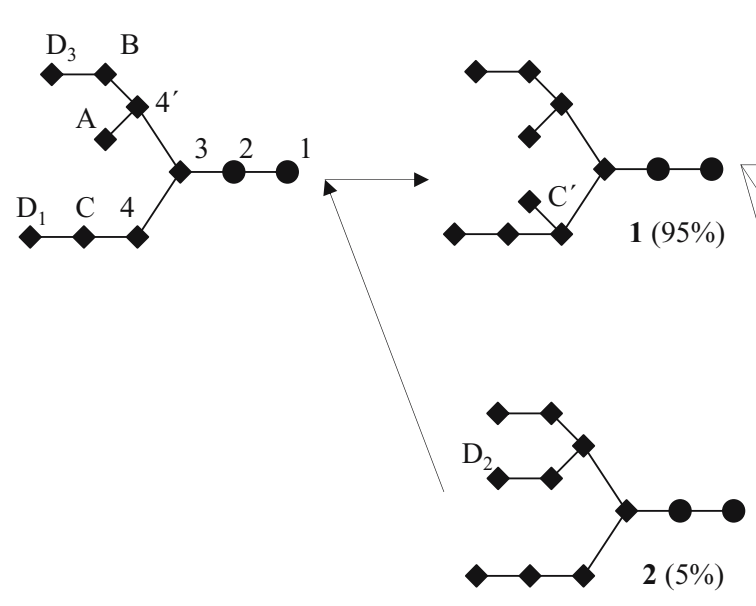

$N$-Acetylglucosamine

- Mannose

/

$(\alpha 1-2)$ linkage

$(\alpha 1-3)$ linkage

$(\alpha 1-6)$ linkage
Q0.M10

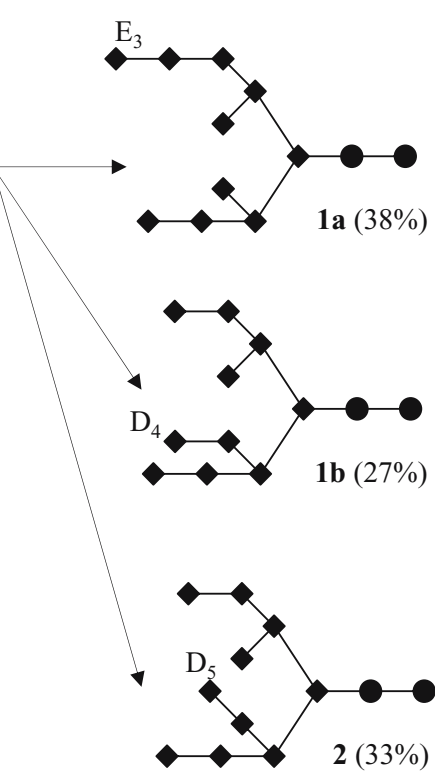

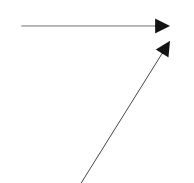

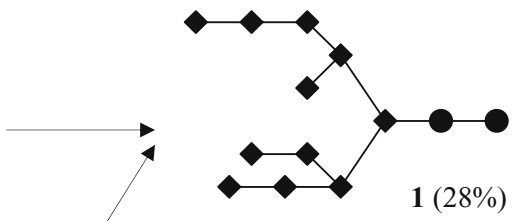

$1(28 \%)$

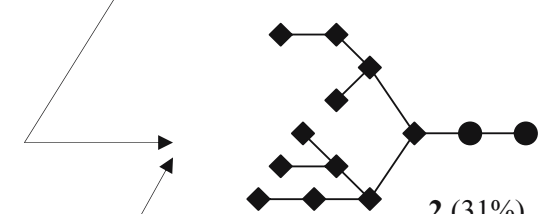

$2(31 \%)$

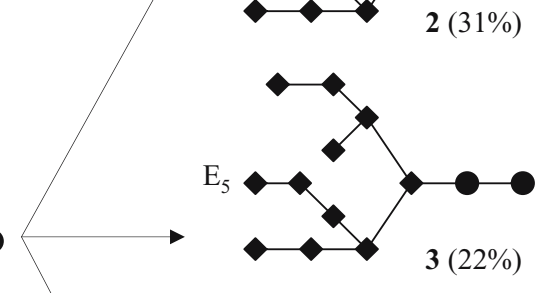

$3(22 \%)$

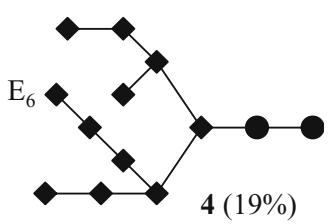

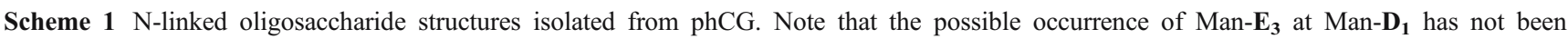
excluded (see text) 
Table $1{ }^{1} \mathrm{H}$-chemical shifts data of the structural-reporter-group protons of the high-mannose-type N-glycans derived from phCG

\begin{tabular}{|c|c|c|c|c|c|c|c|c|c|c|c|c|}
\hline \multirow[t]{3}{*}{ Reporter group } & \multirow[t]{3}{*}{ Residue } & \multicolumn{11}{|c|}{ Chemical shift in ppm } \\
\hline & & \multicolumn{9}{|l|}{ Q0 } & \multicolumn{2}{|l|}{ Q1 } \\
\hline & & M8 & M9-1 & M10-1a & M10-1b & M10-2 & M11-1 & M11-2 & M11-3 & M11-4 & 1 & 2 \\
\hline \multirow[t]{20}{*}{$\mathrm{H}-1$} & GlcNAc- $1 \alpha$ & 5.188 & 5.188 & 5.190 & 5.190 & 5.190 & 5.189 & 5.189 & 5.190 & 5.190 & 5.190 & 5.190 \\
\hline & GlcNAc-1 $\beta$ & n.d. & 4.867 & n.d. & n.d. & n.d. & n.d. & n.d. & n.d. & n.d. & n.d. & n.d. \\
\hline & GlcNAc-2 & 4.60 & 4.60 & 4.60 & 4.60 & 4.60 & 4.60 & 4.60 & n.d. & n.d. & 4.60 & 4.60 \\
\hline & Man-3 & n.d. & n.d. & n.d. & n.d. & n.d. & n.d. & n.d. & n.d. & n.d. & n.d. & n.d. \\
\hline & Man-4 & 5.339 & 5.341 & 5.342 & 5.342 & 5.342 & 5.339 & 5.344 & 5.344 & 5.343 & 5.338 & 5.338 \\
\hline & Man-4' & 4.870 & 4.871 & 4.871 & 4.871 & 4.871 & 4.869 & 4.870 & 4.868 & 4.870 & 4.871 & 4.870 \\
\hline & Man-A & 5.088 & 5.099 & 5.100 & 5.100 & 5.100 & 5.098 & 5.097 & 5.097 & 5.097 & 5.086 & 5.086 \\
\hline & Man-B & 5.146 & 5.145 & 5.144 & 5.144 & 5.144 & 5.142 & 5.145 & 5.143 & 5.143 & 5.144 & 5.141 \\
\hline & Man-C & 5.304 & 5.303 & 5.303 & 5.303 & 5.303 & 5.302 & 5.302 & 5.301 & 5.302 & 5.303 & 5.305 \\
\hline & Man- $\mathbf{C}^{\prime}$ & - & 4.927 & 4.927 & 5.121 & 4.912 & 5.121 & 5.122 & 4.911 & 4.91 & 4.928 & 4.912 \\
\hline & Man-D & 5.043 & 5.047 & 5.049 & 5.049 & 5.049 & 5.049 & 5.049 & 5.049 & 5.047 & 5.048 & 5.049 \\
\hline & Man-D $\mathbf{D}_{\mathbf{3}}$ & 5.043 & 5.043 & 5.303 & 5.049 & 5.042 & 5.302 & 5.049 & 5.049 & 5.047 & 5.048 & 5.049 \\
\hline & Man-D & - & - & - & 5.049 & - & 5.049 & 5.049 & - & - & - & - \\
\hline & Man-D & - & - & - & - & 4.912 & - & 4.929 & 5.121 & 4.91 & - & 4.912 \\
\hline & Man-E $\mathbf{E}_{\mathbf{3}}$ & - & - & 5.049 & - & - & 5.049 & - & - & - & - & - \\
\hline & Man-E $\mathbf{E}_{\mathbf{5}}$ & - & - & - & - & - & - & - & 5.049 & - & - & - \\
\hline & Man-E $\mathbf{E}_{6}$ & - & - & - & - & - & - & - & - & 4.91 & - & - \\
\hline & Man- $P$ & & & & & & & & & & 5.439 & 5.439 \\
\hline & & & & & & & & & & & 5.414 & 5.411 \\
\hline & & & & & & & & & & & & 5.450 \\
\hline \multirow[t]{16}{*}{$\mathrm{H}-2$} & Man-3 & 4.23 & 4.16 & 4.16 & 4.16 & 4.16 & n.d. & n.d. & n.d. & n.d. & n.d. & \\
\hline & Man-4 & 4.09 & 4.09 & 4.09 & 4.09 & 4.09 & 4.09 & 4.09 & 4.09 & 4.09 & 4.09 & \\
\hline & Man-4' & 4.14 & 4.15 & 4.15 & 4.15 & 4.15 & 4.15 & 4.15 & 4.15 & 4.15 & 4.14 & \\
\hline & Man-A & 4.07 & 4.07 & 4.07 & 4.07 & 4.07 & 4.07 & 4.07 & 4.07 & 4.07 & 4.07 & \\
\hline & Man-B & 4.04 & 4.03 & 4.03 & 4.03 & 4.03 & 4.02 & 4.02 & 4.02 & 4.02 & 4.03 & \\
\hline & Man-C & 4.11 & 4.12 & 4.11 & 4.11 & 4.11 & 4.11 & 4.11 & 4.11 & 4.11 & 4.11 & \\
\hline & Man- $\mathbf{C}^{\prime}$ & - & 3.99 & 4.00 & 4.02 & 3.99 & 4.02 & 4.02 & 3.99 & 3.99 & 3.99 & \\
\hline & Man-D & 4.07 & 4.07 & 4.07 & 4.07 & 4.07 & 4.07 & 4.07 & 4.07 & 4.07 & 4.07 & \\
\hline & Man-D & 4.07 & 4.07 & 4.11 & 4.07 & 4.07 & 4.11 & 4.07 & 4.07 & 4.07 & 4.07 & \\
\hline & Man-D & - & - & - & 4.07 & - & 4.07 & 4.07 & - & - & - & \\
\hline & Man-D 5 & - & - & - & - & 3.99 & - & 3.99 & 4.02 & 3.99 & - & \\
\hline & Man-E $\mathbf{E}_{\mathbf{3}}$ & - & - & 4.07 & - & - & 4.07 & - & - & - & - & \\
\hline & Man-E $\mathbf{E}_{\mathbf{5}}$ & - & - & - & - & - & - & - & 4.07 & - & - & \\
\hline & Man-E 6 & - & - & - & - & - & - & - & - & 3.99 & - & \\
\hline & Man- $P$ & & & & & & & & & & 4.00 & \\
\hline & & & & & & & & & & & 3.98 & \\
\hline
\end{tabular}

Chemical shifts are given relative to internal acetone $(\delta 2.225)$ in ${ }^{2} \mathrm{H}_{2} \mathrm{O}$ at $300 \mathrm{~K}$ and at $\mathrm{p}^{2} \mathrm{H} 7$ [41]. n.d. $=$ not determined

a Man $(\alpha 1-2)$ residue (see ${ }^{1} \mathrm{H}-\mathrm{NMR}$ data of $\mathrm{Man}_{10} \mathrm{GlcNAc}_{1}$ compound IIIa in [25]). Consequently, compound Q0.M101b can be formulated as an extension of Q0.M9-1 with a Man- $\mathbf{D}_{\mathbf{4}}$ residue at Man- $\mathbf{C}^{\prime}$. Taking into account the terminal position of Man-A (H-1, $\delta 5.100$; see above) and the fact that Man- $\mathbf{C}^{\prime}$ also occurs in terminal position $(\mathrm{H}-1, \delta$ 4.927), remaining linear extensions can only take place at Man-D $\mathbf{D}_{\mathbf{1}}$ or Man-D $\mathbf{D}_{\mathbf{3}}$ of Q0.M9-1. Previously, based on NMR studies carried out at $23^{\circ} \mathrm{C}$, it has been reported for $\mathrm{Man}_{10} \mathrm{GlcNAc}_{1}$ that in P. pastoris extensions occur prefer-

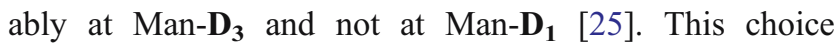

was based on differences in Man-4 H-1 values comparing the Man-D $\mathbf{1}^{-}(\alpha 1-2)-$ Man-C-( $\left.\alpha 1-2\right)-M a n-4$ and Man-C( $\alpha 1-2)$-Man-4 sequences in $\mathrm{Man}_{8} \mathrm{GlcNAc}_{1}$ at $70^{\circ} \mathrm{C}$ (Man$4 \mathrm{H}-1, \Delta \delta=-0.013$ ) (at $23^{\circ} \mathrm{C}$ the Man-4 H-1 chemical shifts are identical) [47] and in $\mathrm{Man}_{6 / 8} \mathrm{GlcNAc-ol}$ at $40^{\circ} \mathrm{C}$ (Man-4 H-1, $\Delta \delta=-0.012$ ) [50]. Like the Man-4 H-1 values of the three $\mathrm{Man}_{8} \mathrm{GlcNAc}_{1}$ isomers at $23^{\circ} \mathrm{C}$, also those of the three $\mathrm{Man}_{8} \mathrm{GlcNAc}_{2}$ isomers have identical chemical shifts at $27^{\circ} \mathrm{C}[37,44,45]$. Based on our NMR data of Q0. M10-1, obtained at 23, 27, 40, and $70^{\circ} \mathrm{C}$, a definite choice for the extension of the additional Man residue, at Man- $\mathbf{D}_{\mathbf{3}}$ 
or at Man- $\mathbf{D}_{1}$, turned out to be not possible. For reasons of readability, in Scheme 1, the location of the additional ( $\alpha 1-$ 2)-linked Man residue $\left(\right.$ Man- $\left.\mathbf{E}_{\mathbf{3}}\right)$ has been set at Man- $\mathbf{D}_{\mathbf{3}}$ (structure Q0.M10-1a); in Table 1 the assignments have also been arranged following an extension of Man- $\mathbf{D}_{\mathbf{3}}$.

The ${ }^{1} \mathrm{H}-\mathrm{NMR}$ spectrum of HPAEC subfraction Q0.M10-2 is very similar to that of Q0.M9-1 (Fig. 7b, Scheme 1, Table 1). Only the Man H-1,H-2 couple at $\delta 4.912 / 3.99$ occurs with double intensity, indicating the presence of an extra Man residue with nearly identical structural reporters as Man-C'. As reported earlier, these signals have been shown to be characteristic for an ( $\alpha 1-6)$-linked Man residue at Man$C^{\prime}$ (Man-D5-( $\left.\left.\alpha 1-6\right)-M a n-C^{\prime}-(\alpha 1-6)-M a n-4\right)$ (see Man $_{10-}$ GlcNAc $_{1}$ compound IIIc in [25]. As mentioned above for Q0.M9-1, also the spectrum of Q0.M10-2 shows a minor separation of the Man-D $\mathbf{D}_{\mathbf{1}}$ and Man-D $\mathbf{3}$ H-1 signals. The fact that Q0.M10-2 has a higher HPAEC retention time than Q0.

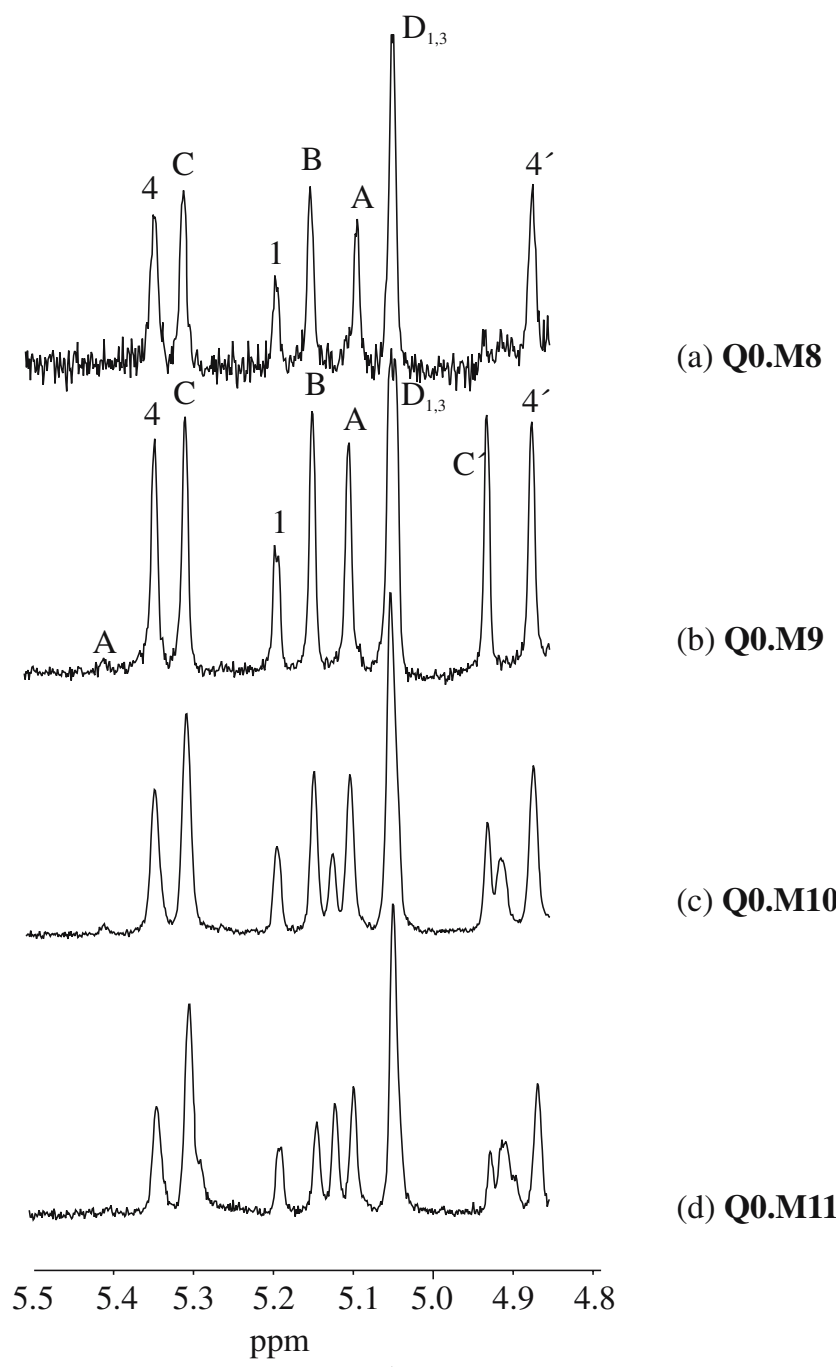

Fig. 5 Anomeric regions of ${ }^{1} \mathrm{H}-\mathrm{NMR}$ spectra of neutral oligosaccharides (a) $\mathrm{Man}_{8} \mathrm{GlNNAc}_{2}$ (Q0.M8), (b) $\mathrm{Man}_{9} \mathrm{GlcNAc}_{2}$ (Q0.M9), (c) $\mathrm{Man}_{10} \mathrm{GlcNAc}_{2}$ (Q0.M10), and (d) $\mathrm{Man}_{11} \mathrm{GlcNAc}_{2}$ (Q0.M11), isolated from $\mathrm{phCG}$
M10-1a and Q0.M10-1b is in agreement with the occurrence of one extra HO2 group in Q0.M10-2 [25, 51, 52].

$\operatorname{Man}_{11}$ GlcNAc $_{2}$ pool

The structural-reporter-group region of the ${ }^{1} \mathrm{H}-\mathrm{NMR}$ spectrum of subfraction Q0.M11 indicated the presence of a mixture of $\operatorname{Man}_{11}$ GlcNAc$_{2}$ isomers (Fig. 5d, Scheme 1, Table 1). The Man-A H-1 signal at $\delta 5.100$ reflects the presence of Man extensions starting from Q0.M9-1; the trace signal at $\delta 5.404$ could indicate very minor amounts of extensions starting from Q0.M9-2. In a similar way as discussed for Q0.M10, also here N-glycans with additional terminal $\alpha(1-3)$-linked Man extensions could be eliminated by inspection of 2D TOCSY spectra of Q0.M11: no H-1,H2 correlation was found at $\delta 5.144 / 4.23$. Compared with the spectrum of Q0.M10, that of Q0.M11 shows various changes in intensities of H-1 signals, related to Man extensions from Man-4 on ( $\delta \sim 4.92$ and 5.122), and to Man- $(\alpha 1-2)$ extensions at Man- $(\alpha 1-2)$ residues $(\delta 5.049$ and 5.302).

The $\mathrm{Man}_{11} \mathrm{GlCNAc}_{2}$ pool was further fractionated by HPAEC (Fig. 6b), and four subfractions were isolated, Q0. M11-1 (28\%), Q0.M11-2 (31\%), Q0.M11-3 (22\%), and Q0.M11-4 (19\%), which were checked by MALDI-TOFMS to be pure $\operatorname{Man}_{11} \mathrm{GlcNAc}_{2}$ isomers.

The ${ }^{1} \mathrm{H}-\mathrm{NMR}$ spectrum of HPAEC subfraction Q0.M11$\mathbf{1}$ is in accordance with structure Q0.M10-1b extended with Man-E $\mathbf{E}_{\mathbf{3}}$ (Fig. 8a, Scheme 1, Table 1). However, one should keep in mind that for reasons outlined above for Q0.M101a, a definite choice for the extension of the additional Man residue, at Man- $\mathbf{D}_{\mathbf{3}}$ or at Man- $\mathbf{D}_{\mathbf{1}}$, is not possible.

The ${ }^{1} \mathrm{H}-\mathrm{NMR}$ spectrum of HPAEC subfraction Q0.M11$\mathbf{2}$ is in accordance with structure Q0.M10-1b extended with Man-D 5 or structure Q0.M10-2 extended with Man-D $\left(\right.$ Man-C' at $\delta 5.122$ and Man-D $\mathbf{D}_{5}$ at $\delta$ 4.929) (Fig. 8b, Scheme 1, Table 1). The ${ }^{1} \mathrm{H}-\mathrm{NMR}$ data are in good agreement with those reported earlier for $\operatorname{Man}_{11}$ GlcNAc $_{1}$ compound $\mathrm{IVb}$ [25]. A possible reason for the unusual low intensity of Man-B H-1 ( $\delta$ 5.145) has already been discussed for Q0.M10-1. The presence of the additional signal at $\delta 5.288$ could correspond with a Man-D $\mathbf{D}_{\mathbf{1}} \mathrm{H}-1$ signal, supporting a Man- $(\alpha 1-2)$ extension at Man-D instead of at Man-C'. Therefore, it is suggested that Q0. M11-2 contains besides Q0.M11-2 also this isomer.

The ${ }^{1} \mathrm{H}-\mathrm{NMR}$ spectrum of HPAEC subfraction Q0.M11$\mathbf{3}$ is in accordance with structure Q0.M10-2 extended with Man-E $\mathbf{5}_{\mathbf{5}}$ (Fig. 8c, Scheme 1, Table 1). The same intensity problem for Man-B as in the previous compound is observed. Comparison of the spectra of Q0.M11-3 and Q0.M10-2 learns that the chemical shift of Man-C' $\mathrm{H}-1(\delta$ 4.911) remains the same, but Man- $\mathbf{D}_{5}$ becomes $(\alpha 1-2)$ substituted (H-1 at $\delta 5.121)$ by Man-E $\mathbf{E}_{\mathbf{5}}$. These data are in 
Fig. 6 HPAEC profile using pulsed amperometric detection of (a) fraction Q0.M10 and (b) fraction Q0.M11 on a CarboPac PA-1 column. Elutions were carried out with a gradient of sodium acetate in $\mathrm{NaOH}$ (see Materials and methods)

\section{PAD response $(\mathrm{nC})$}

(a) Q0.M10
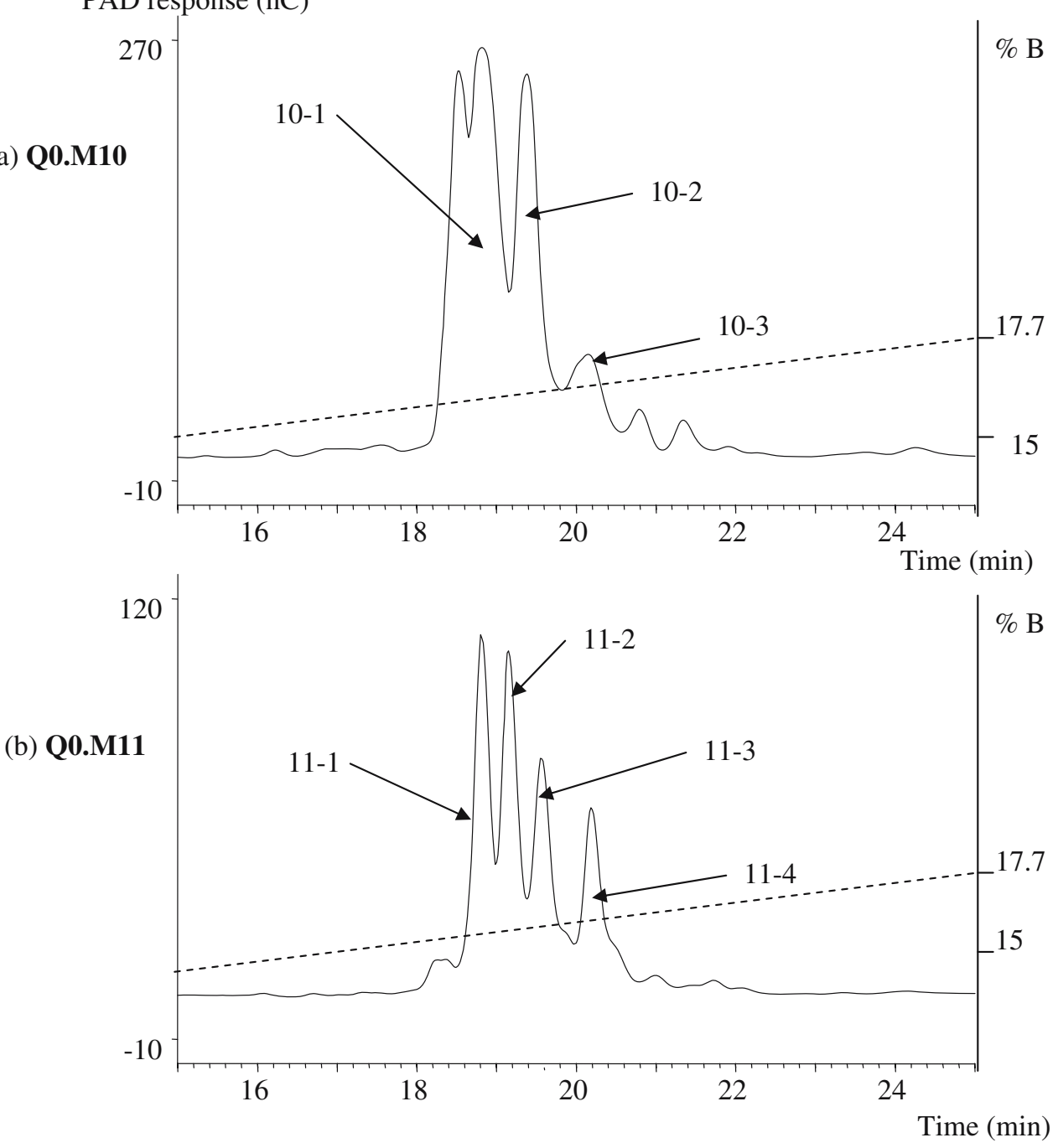

accordance with the increase in intensity observed for the H-1 signal corresponding with terminal Man- $(\alpha 1-2)(\delta$ 5.049) (see also compound IV-C in [25]). The relatively high signal at $\delta 5.301$ could reflect a Man- $(\alpha 1-2)$ extension at Man- $\mathbf{D}_{1}$, as discussed for Q0.M11-2.

The ${ }^{1} \mathrm{H}-\mathrm{NMR}$ spectrum of HPAEC subfraction Q0.M114 is in accordance with structure Q0.M10-2 extended with Man- $\mathbf{E}_{\mathbf{6}}$ (Fig. 8d, Scheme 1, Table 1). The ( $\left.\alpha 1-6\right)$-region at $\delta 4.91$ integrates to about three protons, reflecting the sequence Man-E $\mathbf{6}^{-}(\alpha 1-6)-$ Man-D $_{5^{-}}(\alpha 1-6)-$ Man- $\mathbf{C}^{\prime}$.

\section{Charged oligosaccharides Q1}

The pool of charged N-glycans Q1 was characterized in terms of molecular mass by MALDI-TOF-MS. In Fig. $2 b$ its negative-ion mode mass spectrum is depicted, showing that the compounds range from $\mathrm{Man}_{9} P \mathrm{GlNNAc}_{2}$ to $\mathrm{Man}_{13}$ $P \mathrm{GlNNAc}_{2}$. Fractionation of FPLC fraction $\mathbf{Q 1}$ by normalphase HPLC on Lichrosorb- $\mathrm{NH}_{2}$ gave rise to three subfractions denoted Q1-1 to Q1-3 (Fig. 4b), which were analyzed by MALDI-TOF-MS to show that in terms of molecular mass Q1-1 contained $\mathrm{Man}_{9-11} P \mathrm{GlNAC}_{2}, \mathbf{Q 1 - 2}$ $\mathrm{Man}_{10-12} P \mathrm{GlNNAc}_{2}$, and Q1-3 $\mathrm{Man}_{12-13} P \mathrm{GlcNAc}_{2}$, dem-

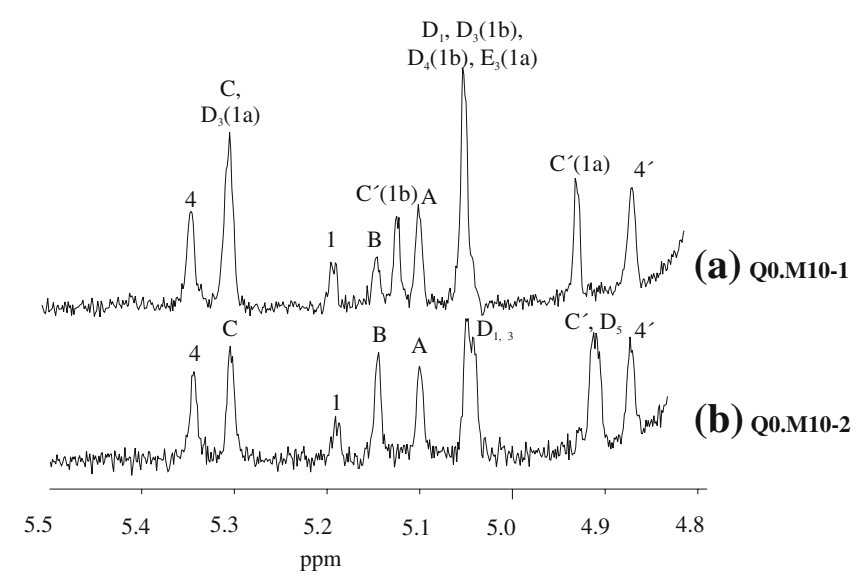

Fig. 7 Anomeric regions of ${ }^{1} \mathrm{H}-\mathrm{NMR}$ spectra of subfractions (a) Q0.M10-1 and (b) Q0.M10-2, isolated from phCG 


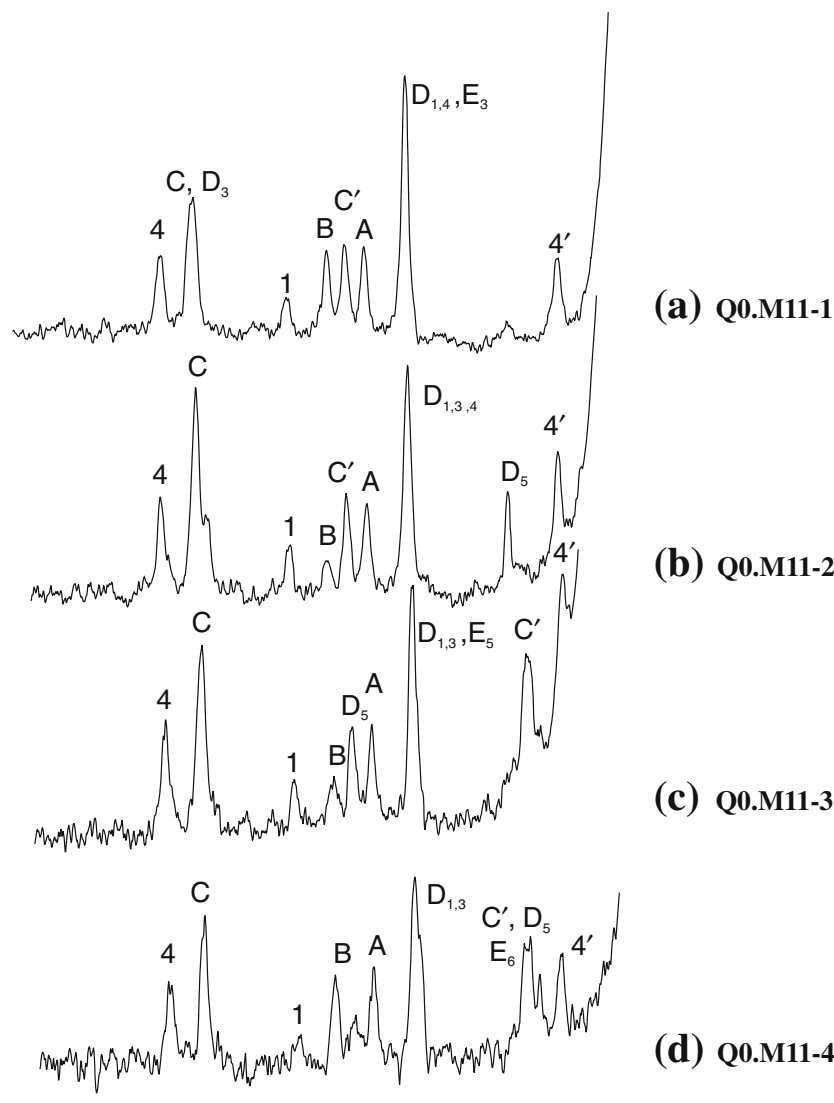

\begin{tabular}{llllllll}
\hline 5.5 & 5.4 & 5.3 & $\begin{array}{c}5.2 \\
\text { ppm }\end{array}$ & 5.1 & 5.0 & 4.9 & 4.8
\end{tabular}

Fig. 8 Anomeric regions of ${ }^{1} \mathrm{H}-\mathrm{NMR}$ spectra of subfractions (a) Q0. M11-1, (b) Q0.M11-2, (c) Q0.M11-3, and (d) Q0.M11-4, isolated from $\mathrm{phCG}$

onstrating a poor subfractionation. Subfractions Q1-1, Q12, and Q1-3 were further investigated by HPLC profiling, and Q1-1 and Q1-2 by 500-MHz ${ }^{1} \mathrm{H}$ NMR spectroscopy; subfraction Q1-3 did not contain sufficient material for NMR analysis.

\section{Q1-1 pool $\left(\mathrm{Man}_{9-11} \mathrm{PGlcNAc}_{2}\right)$}

The HPLC profile (weak anion-exchange Vydac 301 VHP5410 column) of the 2AB-derivatized pool of $\mathrm{N}$ glycans Q1-1 revealed three peaks, A, B, and C, in the charged region of the chromatogram (Fig. 9a). Treatment of subfraction Q1-1 with alkaline phosphatase, cleaving only terminal phosphate groups, led to the disappearance of peak $\mathrm{C}$ (Fig. 9b), indicating that $\mathrm{C}$ corresponds to structures with a dicharged terminal phosphate group that have become neutral after digestion ( $P$-Man- $\rightarrow$ Man-) (data not shown). Positive-ion mode MALDI-TOF-MS of alkaline phosphatase-treated subfraction Q1-1 demonstrated the presence of neutral $\mathrm{Man}_{9-11} \mathrm{GlcNAc}_{2}$, in accordance with structures of Q1-
1 before alkaline phosphatase treatment $\left(\mathrm{Man}_{9-11} P \mathrm{GlcNAc}_{2}\right)$. Treatment of subfraction Q1-1 with mild acid led to a shift of the position of peak A to that of peak C (Fig. 9c), indicating that A corresponds to structures with an acid-labile monocharged diesterified phosphate group (Man- $P$-Man- $\rightarrow$ $P$-Man-) [28]. Peak B seems to be a mixture of structures with terminal or diesterified phosphate groups, as deduced from the observation that peak B totally disappears only after both alkaline phosphatase and mild acid incubations. The presence of both diesterified and monoesterified phosphates in Q1-1 could be due to partial chemical decapping of phosphate during sample handling. Previously, the labilility of Man- $P$-Man-linkages during work-up procedures of $S$. cerevisiae mannoprotein has been mentioned [53].

The structural-reporter-group region of the ${ }^{1} \mathrm{H}-\mathrm{NMR}$ spectrum of subfraction Q1-1 (Fig. 10a, Table 1) is very similar to that of $\mathrm{Man}_{9} \mathrm{GlcNAc}_{2}$ (Q0.M9-1; Fig. 5b). The two additional "doublets" at $\delta 5.439\left(J_{\mathrm{H}-1, \mathrm{P}}=8.0 \mathrm{~Hz}\right)$ and $5.414\left(J_{\mathrm{H}-1, \mathrm{P}}=7.5 \mathrm{~Hz}\right)$ reflect the presence of at least two types of $\alpha$ Man- $P$-groups $[54,55]$. In $S$. cerevisiae yeast glycoproteins, phosphate groups are attached to HO6 of Man-B and/or Man-C within the oligosaccharide chain [53]. As subfraction Q1-1 contains mainly $\operatorname{Man}_{10} P \mathrm{GlNNAc}_{2}$ (MALDI-TOF-MS), and taking into account the various NMR data, it is suggested that subfraction Q1-1 contains, at any case, compounds Q0.M9-1 with Man- $P$-extensions. For

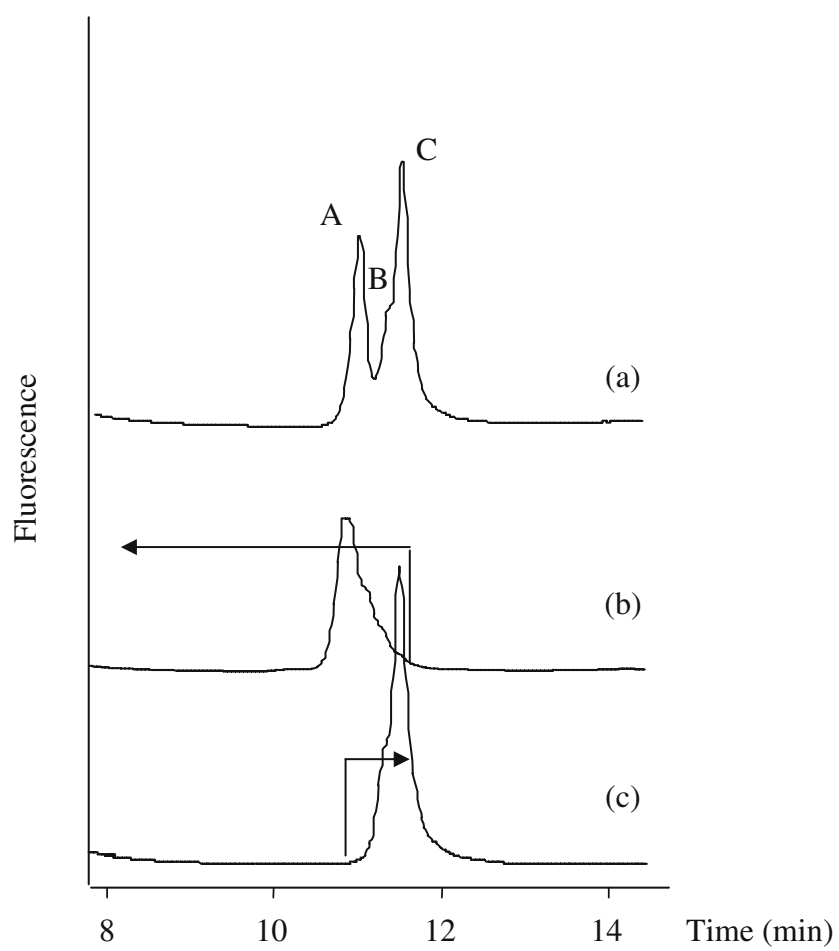

Fig. 9 HPLC profile of the fluorescent 2AB-labeled oligosaccharide mixture Q1-1 before and after solvolysis on a weak anion-exchange column at a flow rate of $0.4 \mathrm{ml} / \mathrm{min}$ and a gradient of ammonium formate, $\mathrm{pH}$ 4.4, in acetonitrile. (a) Q1-1; (b) Q1-1 after alkaline phosphatase digestion; (c) Q1-1 after mild acid hydrolysis 


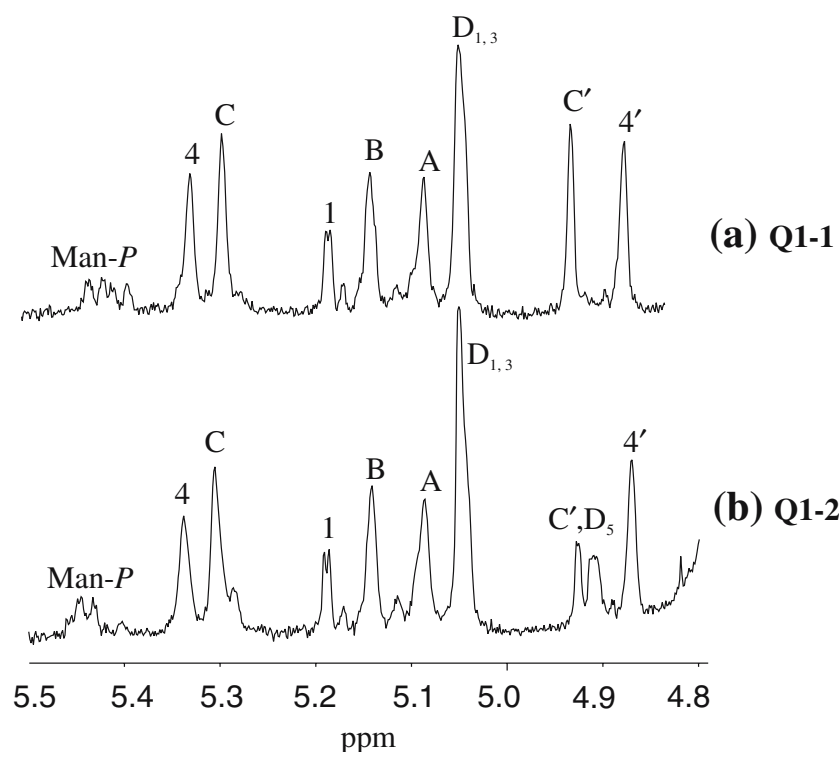

Fig. 10 Anomeric regions of $1 \mathrm{D}{ }^{1} \mathrm{H}-\mathrm{NMR}$ spectra of charged fractions (a) Q1-1 and (b) Q1-2, isolated from phCG

$\operatorname{Man}_{\mathrm{x}} \mathrm{GlcNAc}_{1}$ structures, a Man- $P$-extension on Man-B has been shown to induce a shift for Man-A H-1 of $\Delta \delta=-0.008$ (compare structure B in [43] with structure I in [53]); no shifts are observed for Man-B and Man-D $\mathbf{D}_{3} \mathrm{H}-1$. Comparison of the Man-A H-1 signals in Q0.M9-1 ( 8 5.099) and in Q1-1 ( $\delta$ 5.086) shows a similar upfield shift $(\Delta \delta=-0.013)$, thereby supporting the presence of a component Q0.M9-1 mannophosphorylated at HO6 of Man-B; in ManPMan ${ }_{9}$ Glc$\mathrm{NAc}_{2}$, Man- $\mathbf{D}_{3} \mathrm{H}-1$ is slightly $(\Delta \delta=-0.005)$ influenced. For $\mathrm{Man}_{\mathrm{x}} \mathrm{GlcNAc}_{1}$ structures, a Man- $P$-extension on Man-C caused an upfield shift of Man-C H-1 of $\Delta \delta=-0.019$ (compare structure B in [43] with structure IV in [53]). Such a shift is not observed comparing the Man- $\mathbf{C ~ H - 1}$ values in Q0.M9-1 and Q1-1. As already discussed above, increments detected for ${ }^{1} \mathrm{H}-\mathrm{NMR}$ values of the $\mathrm{Man}_{\mathrm{x}} \mathrm{GlcNAc}_{1}$ series seems to be not always transferable to the $\mathrm{Man}_{\mathrm{x}} \mathrm{GlNNAc}_{2}$ series, and problems were detected with respect to the Man$D_{1}$-Man-C-Man-4 sequence. Having two clear $\alpha$ Man- $P$ H-1 signals in the ${ }^{1} \mathrm{H}-\mathrm{NMR}$ spectrum, it is therefore hypothesized that a component Q0.M9-1 mannophosphorylated at HO6 of Man-C is also present. The relatively low intensities of the two $\alpha$ Man- $P \mathrm{H}-1$ signals support the presence of $\mathrm{Man}_{9-11} \mathrm{GlcNAc}_{2}$ structures, only phosphorylated on one of the two residues. The small H-1 signal at $\delta 5.120$ (Man-D $\mathbf{D}^{-}$ $(\alpha 1-2)$-Man- $\mathbf{C}^{\prime}$ segment) suggests at any case the presence of a phospho-extended structure Q0.M10-1b.

Q1-2 and Q1-3 pools ( $\operatorname{Man}_{10-12} P_{\text {GlcNAc }}$ and $\mathrm{Man}_{12-13} P \mathrm{GlcNAc}_{2}$ )

The HPLC profiles of the 2AB-derivatized pools of Nglycans Q1-2 and Q1-3 were similar to that of Q1-1, and behaved in the same way when incubated with alkaline phosphatase or mild acid. Consequently, also subfractions Q1-2 and Q1-3 contain mixtures of structures with $P$-Man and Man- $P$-Man elements.

The structural-reporter-group region of the ${ }^{1} \mathrm{H}-\mathrm{NMR}$ spectrum of subfraction Q1-2 (Fig. 10b, Table 1) shows a major characteristic doublet at $\delta 5.439\left(J_{\mathrm{H}-1, \mathrm{P}}=8.0 \mathrm{~Hz}\right)$ and two minor ones at $\delta 5.411\left(J_{\mathrm{H}-1, \mathrm{P}}=7.5 \mathrm{~Hz}\right)$ and $\delta 5.450$ $\left(J_{\mathrm{H}-1, \mathrm{P}}=8.0 \mathrm{~Hz}\right)$, in agreement with the presence of $\alpha$ Man$P$-groups $[54,55]$. As indicated by MALDI-TOF-MS, subfraction Q1-2 contains mainly $\operatorname{Man}_{11} P \mathrm{GlcNAc}_{2}$. In view of the broad H-1 signal at $\delta 4.912$, also present in the ${ }^{1} \mathrm{H}$ NMR spectrum of Q0.M10-2 (Man- $\mathbf{C}^{\prime}$ and Man-D $\mathbf{D}_{\mathbf{5}}$ ), it is suggested that Q1-2 contains at least a Man- $P$-extension of Q0.M10-2. The Man-A H-1 signal at $\delta 5.086$ supports a mannophosphorylation at HO6 of Man-B. The relative low intensities of the three $\alpha$ Man- $P \mathrm{H}-1$ signals support the presence of $\mathrm{Man}_{10-12} \mathrm{GlcNAc}_{2}$ structures, only phosphorylated on one of the two residues. The signals at $\delta 5.285$, 5.122, and 4.929 correspond with Man-C, Man- $\mathbf{C}^{\prime}$, and Man-D 5 signals also present in Q0.M11-2.

Charged oligosaccharides Q2

The amount of the pool of charged N-glycans of Q2 was not sufficient for NMR studies or HPLC subfractionation. To gain some information about the components of the fraction, weak-anion HPLC profiling was conducted after $2 \mathrm{AB}$ derivatization. The chromatogram showed two peak

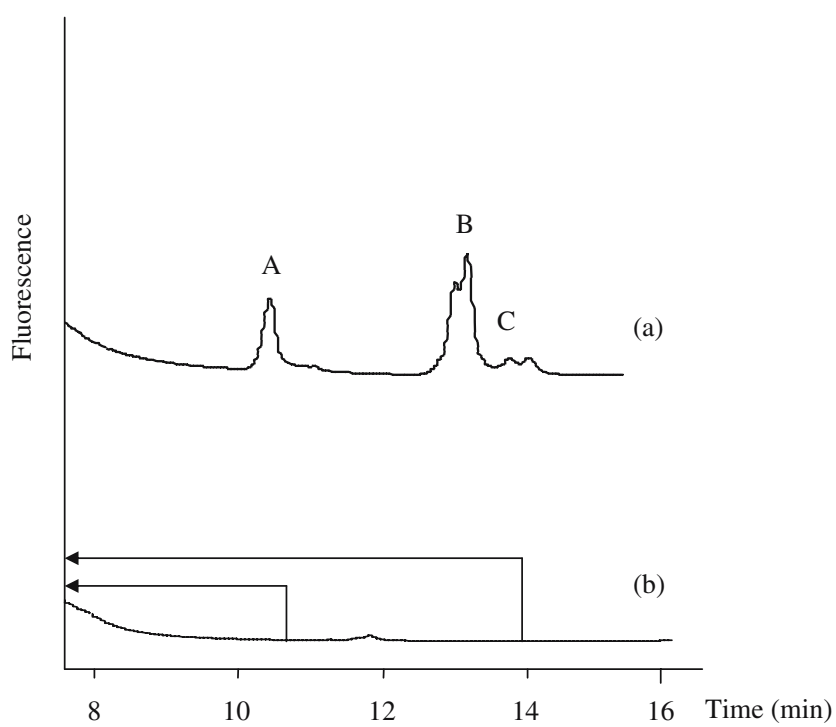

Fig. 11 HPLC profile of the fluorescent 2AB-labeled oligosaccharide mixture Q2 before and after solvolysis on a weak anion-exchange column at a flow rate of $0.4 \mathrm{ml} / \mathrm{min}$ and a gradient of ammonium formate, $\mathrm{pH}$ 4.4, in acetonitrile. (a) Q2 and Q2 after alkaline phosphatase digestion; (b) $\mathbf{Q} 2$ after mild acid hydrolysis and alkaline phosphatase digestion 
Table 2 Carbohydrate chains occurring in phCG produced in batch I and batch II

Results are based on peak areas of the 2AB-chromatograms

\begin{tabular}{|c|c|c|c|c|}
\hline & \multicolumn{2}{|c|}{ Batch I } & \multicolumn{2}{|c|}{ Batch II } \\
\hline & $\alpha$ & $\beta$ & $\alpha$ & $\beta$ \\
\hline $\mathrm{Man}_{8} \mathrm{GlcNAc}_{2}$ & 17 & 18 & 4 & 5 \\
\hline $\mathrm{Man}_{9} \mathrm{GlcNAc}_{2}$ & 39 & 41 & 32 & 24 \\
\hline $\operatorname{Man}_{10} \mathrm{GlcNAc}_{2}$ & 30 & 24 & 37 & 36 \\
\hline $\operatorname{Man}_{11} \mathrm{GlcNAc}_{2}$ & 11 & 13 & 23 & 29 \\
\hline $\operatorname{Man}_{12} \mathrm{GlcNAc}_{2}$ & 3 & 4 & 4 & 6 \\
\hline
\end{tabular}

areas $\mathrm{A}$ and $\mathrm{B}+\mathrm{C}$ in the acidic region, with a relevant difference in retention time (Fig. 11). After treatment with alkaline phosphatase, the HPLC peak pattern of Q2 did not change, indicating the absence of $P$-Man-elements. Mild acid hydrolysis followed by an alkaline phosphatase digestion resulted in the complete disappearance of the charged components' peaks. Taking into account their retention times, it is speculated that peak A reflects glycans with one terminal Man- $P$-Man motif, and peaks $\mathrm{B}+\mathrm{C}$ glycans with two terminal Man- $P$-Man motifs [28].

Profiling studies of $\alpha$-phCG and $\beta$-phCG from phGC batches I and II

To compare the influence of the culturing medium on the $\mathrm{N}$ glycosylation pattern of $P$. pastoris expressed hCG (phCG), two protocols were applied, yielding phCG batch I and phCG batch II. For batch I, ammonia was used as nitrogen source; for batch II, ammonium sulfate. Both batches were subjected to reduction, carboxymethylation, and separation of the $\alpha$ - and $\beta$-subunits on Superdex G75. MALDI-TOFMS of $\alpha$-phCG showed a molecular mass of $15 \mathrm{kDa}$, corresponding to about $11 \mathrm{kDa}$ of protein backbone and 2 $\mathrm{N}$-glycans of a mass in the range of $2 \mathrm{kDa}$ each. For $\beta-\mathrm{hCG}$ these values are $19 \mathrm{kDa}$, about $15 \mathrm{kDa}$, and about $4 \mathrm{kDa}$ reflecting $2 \mathrm{~N}$-glycans, respectively.

The 4 samples were digested with PNGase F, and SDSPAGE was used to verify the completeness of the de-Nglycosylation. The released free N-glycans of $\alpha$-phCG I, $\beta$-phCG I, $\alpha$-phCG II, and $\beta$-phCG II were converted into their 2AB-labeled derivatives, and analyzed by MALDITOF-MS and HPLC.

As is evident from Table 2, the same neutral high mannosetype structures were present in both batches, but in different proportions. $\alpha$ - and $\beta$-phCG batch I contained higher amounts of $\mathrm{Man}_{8} \mathrm{GlcNAc}_{2}$ and $\mathrm{Man}_{9} \mathrm{GlcNAc}_{2}$ than $\alpha$ - and $\beta$-phCG batch II. The reverse held for $\mathrm{Man}_{10} \mathrm{GlcNAc}_{2}$ and $\mathrm{Man}_{11-}$ GlcNAc $_{2}$. In both batches, $\mathrm{Man}_{12} \mathrm{GlcNAc}_{2}$ was a minor compound. Significant differences in size of the glycans on the subunits of a given batch were not observed. The profiles of the charged glycans showed identical patterns for the two batches and their subunits. It seems that the conditions used for the preparation of batch II induces more biosynthetic processing than those used for batch I.

\section{Discussion}

Structural analysis of the N-glycans of hCG expressed in the methylotrophic yeast Pichia pastoris has resulted in the identification of a pool of $80 \%$ neutral N-glycans and $20 \%$ charged (phosphorylated) N-glycans. Neutral N-glycans could be detected in the range of $\mathrm{Man}_{8} \mathrm{GlcNAc}_{2}$ to $\mathrm{Man}_{15} \mathrm{GlcNAc}_{2}$. Based on MS, HPLC and NMR studies, for 10 components structures could be elucidated. Phosphorylated $\mathrm{N}$-glycans were found in the range of $\mathrm{Man}_{9}$ $P$ GlcNAc 2 to $\operatorname{Man}_{13} P$ GlcNAc 2 . Both Man- $P$-Man- and $P$ Man-elements were detected, but probably $P$-Man-elements were introduced during work-up. The majority of the Nglycans contained 9 to 10 Man residues, independent on the chosen culturing process, whereby $\mathrm{Man}_{9} \mathrm{GlcNAc}_{2}$ nearly only represents the typical yeast isomer. However, culturing conditions did influence the molar ratio within $\mathrm{Man}_{8-}$ ${ }_{12} \mathrm{GlcNAc}_{2}$. It should be noted that previous NMR structural studies of yeast glycoprotein N-glycans were always carried out on $\operatorname{Man}_{\mathrm{x}}\left(P_{\mathrm{y}}\right) \mathrm{GlcNAc}_{1}$ compounds; in the present investigation NMR data of $\operatorname{Man}_{\mathrm{x}}\left(P_{\mathrm{y}}\right) \mathrm{GlcNAc}_{2}$ compounds are presented.

As urinary $\beta$-hCG contains O-linked glycans, and in view of the fact that $P$. pastoris-expressed glycoproteins can be O-mannosylated [29-32], $\beta$-phCG was checked for Omannosylation. Monosaccharide analysis performed on $\mathrm{N}$ deglycosylated phCG did not show any sugar constituent. In addition, MALDI-TOF-MS of $\beta$-phCG showed a molecular mass of $19 \mathrm{kDa}$, corresponding to about $15 \mathrm{kDa}$ of protein backbone and $2 \mathrm{~N}$-glycans of a mass in the range of $2 \mathrm{kDa}$ each.

In conclusion, as expected, in the $P$. pastoris-expressed hCG (phCG), the glycosylation pattern is totally different from that of urinary hCG. However, earlier studies have already shown that, like urinary hCG, phCG is biologically active [23]. Both glycohormones show the same receptorbinding potential, and stimulate testosterone production by mouse Leydig cells and progesterone production by MA-10 
cells. The present study on non-O-glycosylated phCG also shows that the O-glycosylation of $\beta$-hCG seems to have little influence on receptor binding and signal transduction, in accordance with earlier studies on urinary hCG [56]. In several studies, the importance of the $\mathrm{N}$-glycosylation at Asn 52 of urinary $\alpha$-hCG for steroidogenic activity has been shown [56, 57], and it has been postulated that the bulky and extended glycan at this site could have a function in inducing and stabilizing a conformational change in hCG upon binding to the receptor [58]. It is suggested that the high-mannose-type $N$-glycans on $\alpha$ Asn 52 in phCG accomplish the same function.

Acknowledgment This research has been financially supported by the Council for Chemical Sciences of the Netherlands Organization for Scientific Research (CW-NWO).

\section{References}

1. Talwar, G.P.: Human chorionic gonadotropin and ovarian and placental steroidogenesis. J. Steroid Biochem. 11, 27-34 (1979)

2. Endo, T., Yamashita, K., Tachibana, Y., Tojo, S., Kobata, A.: Structures of the asparagine-linked sugar chains of human chorionic gonadotropin. J. Biochem. (Tokyo) 85, 669-679 (1979)

3. Blithe, D.L.: Carbohydrate composition of the $\alpha$-subunit of human chorionic gonadotropin $(\mathrm{hCG} \alpha)$ and the free $\alpha$ molecules produced in pregnancy: most free $\alpha$ and some combined hCG $\alpha$ molecules are fucosylated. Endocrinology 126, 2788-2799 (1990)

4. Weisshaar, G., Hiyama, J., Renwick, A.G.C.: Site-specific $N$ glycosylation of human chorionic gonadotropin, Structural analysis of glycopeptides by one- and two-dimensional ${ }^{1} \mathrm{H}$ NMR spectroscopy. Glycobiology 1, 393-404 (1991)

5. Damm, J.B.L., Voshol, H., Hård, K., Kamerling, J.P., van Dedem, G.W.K., Vliegenthart, J.F.G.: The $\beta$-subunit of human chorionic gonadotropin contains $N$-glycosidic trisialo tri- and tri'-antennary carbohydrate chains. Glycoconj. J. 5, 221-233 (1988)

6. Damm, J.B.L., Kamerling, J.P., van Dedem, G.W.K., Vliegenthart, J.F.G.: A general strategy for the isolation of carbohydrate chains from N-,O-glycoproteins and its application to human chorionic gonadotrophin. Glycoconj. J. 4, 129-144 (1987)

7. Amano, J., Nishimura, R., Mochizuki, M., Kobata, A.: Comparative study of the mucin-type sugar chains of human chorionic gonadotropin present in the urine of patients with trophoblastic diseases and healthy pregnant women. J. Biol. Chem. 263, 11571165 (1988)

8. Liu, C.L., Bowers, L.D.: Mass spectrometry characterisation of the beta-subunit of human chorionic gonadotropin. J. Mass Spectrom. 32, 33-42 (1997)

9. Cole, L.A.: Distribution of O-linked sugar units on hCG and its free alpha-subunit. Mol. Cell. Endocrinol. 50, 45-57 (1987)

10. Bielinska, M., Boime, I.: The glycoprotein hormone family: structure and function of the carbohydrate chains. In: Montreuil, J., Vliegenthart, J.F.G., Schachter, H. (eds.) Glycoproteins, Vol. 29a, pp. 565-587. New Comprehensive Biochemistry, Elsevier Science BV, Amsterdam, The Netherlands (1995)

11. Kamerling, J.P., Hård, K., Vliegenthart, J.F.G.: Structural analysis of carbohydrate chains of native and recombinant-DNA glyco- proteins. In: Crommelin, D.J.A., Schellekens, H. (eds.) Developments in Biotherapy, Vol. 1, From Clone to Clinic, pp. 295-304. Kluwer Academic Publishers, Dordrecht, The Netherlands (1990)

12. Gervais, A., Hammel, Y.-A., Pelloux, S., Lepage, P., Baer, G., Carte, N., Sorokine, O., Strub, J.-M., Koerner, R., Leize, E., Van Dorsselaer, A.: Glycosylation of human recombinant gonadotrophins: characterization and batch-to-batch consistency. Glycobiology 13, 179-189 (2003)

13. Lustbader, J.W., Birken, S., Pollak, S., Pound, A., Chait, B.T., Mirza, U.A., Ramnarain, S., Canfield, R.E., Brown, J.M.: Expression of human chorionic gonadotropin uniformly labeled with NMR isotopes in Chinese hamster ovary cells: An advance toward rapid determination of glycoprotein structures. J. Biomol. NMR 7, 295-304 (1996)

14. Chen, W., Shen, Q.X., Bahl, O.P.: Carbohydrate variant of the recombinant beta-subunit of human choriogonadotropin expressed in baculovirus expression system. J. Biol. Chem. 266, 4081-4087 (1991)

15. Chen, W., Bahl, O.P.: Recombinant carbohydrate variant of human choriogonadotropin beta-subunit (hCGbeta) descarboxyl terminus (115-145). Expression and characterization of carboxylterminal deletion mutant of hCG beta in the baculovirus system. J. Biol. Chem. 266, 6246-6251 (1991)

16. Chen, W., Bahl, O.P.: Recombinant carbohydrate and selenomethionyl variants of human choriogonadotropin. J. Biol. Chem. 266, 8192-8197 (1991)

17. Jung, E., Williams, K.L.: The production of recombinant glycoproteins with special reference to simple eukaryotes including Dictyostelium discoideum. Biotechnol. Appl. Biochem. 25, 3-8 (1997)

18. Linskens, M.H.K., Grootenhuis, P.D.J., Blaauw, M., Huisman-de Winkel, B., van Ravenstein, A., van Haastert, P.J.M., Heikoop, J. C.: Random mutagenesis and screening of complex glycoproteins: expression of human gonadotropins in Dictyostelium discoideum. FASEB J. 13, 639-645 (1999)

19. Peters, B.P., Krzesicki, R.F., Hartle, R.J., Perini, F., Ruddon, R. W.: A kinetic comparison of the processing and secretion of the alpha beta dimer and the uncombined alpha and beta subunits of chorionic gonadotropin synthetized by human choriocarcinoma cells. J. Biol. Chem. 258, 15123-15130 (1984)

20. Cole, L.A., Kroll, T.D., Ruddon, R.W., Hussa, R.O.: Differential occurrence of free beta and free alpha subunits of human chorionic gonadotropin (hCG) in pregnancy sera. J. Clin. Endocrinol. Metab. 58, 1200-1202 (1984)

21. Lustbader, J., Birken, S., Pollak, S., Levinson, L., Berstine, E., Hsiung, N., Cornfield, R.: Characterization of the expression products of recombinant human choriogonadotropin and subunits. J. Biol. Chem. 262, 14204-14212 (1987)

22. Sen Gupta, C., Dighe, R.R.: Hyperexpression of biologically active human chorionic gonadotropin using the methylotropic yeast, Pichia pastoris. J. Mol. Endocrinol. 22, 273-283 (1999)

23. Gadkari, R., Deshpande, R., Dighe, R.R.: Hyperexpression and purification of biologically active human luteinizing hormone and human chorionic gonadotropin using the methylotrophic yeast, Pichia pastoris. Protein Expr. Purif. 32, 175-184 (2003)

24. Grinna, L.S., Tschopp, J.F.: Size distribution and general structural features of N-linked oligosaccharides from the methylotrophic yeast, Pichia pastoris. Yeast 5, 107-115 (1989)

25. Trimble, R.B., Atkinson, P.H., Tschopp, J.F., Townsend, R.R., Maley, F.: Structure of oligosaccharides on Saccharomyces SUC2 invertase secreted by the methylotrophic yeast Pichia pastoris. J. Biol. Chem. 266, 22807-22817 (1991)

26. Miele, R.G., Nilsen, S.L., Brito, T., Bretthauer, R.K., Castellino, F.J.: Glycosylation properties of the Pichia pastoris-expressed recombinant kringle 2 domain of tissue-type plasminogen activator. Biotechnol. Appl. Biochem. 25, 151-157 (1997) 
27. Gemmill, T.R., Trimble, R.B.: Overview of N- and O-linked oligosaccharide structures found in various yeast species. Biochim. Biophys. Acta 1426, 227-237 (1999)

28. Hirose, M., Kameyama, S., Ohi, H.: Characterization of N-linked oligosaccharides attached to recombinant human antithrombin expressed in the yeast Pichia pastoris. Yeast 19, 1191-1202 (2002)

29. Boraston, A.B., Sandercock, L.E., Warren, R.A.J., Kilburn, D.G.: O-Glycosylation of a recombinant carbohydrate-binding module mutant secreted by Pichia pastoris. J. Mol. Microbiol. Biotechnol. 5, 29-36 (2003)

30. Cereghino, J.L., Cregg, J.M.: Heterologous protein expression in the methylotrophic yeast Pichia pastoris. FEMS Microbiol. Rev. 24, 45-66 (2000)

31. Letourneur, O., Gervasi, G., Gaïa, S., Pagès, J., Watelet, B., Jolivet, M.: Characterization of Toxoplasma gondii surface antigen I (SAGI) secreted from Pichia pastoris: evidence of hyper Oglycosylation. Biotechnol. Appl. Biochem. 33, 35-45 (2001)

32. González, L.J., Cremata, J.A., Guanche, Y., Ramos, Y., Triguero, A., Cabrera, G., Montesino, R., Huerta, V., Pons, T., Boué, O., Farnós, O., Rodríguez, M.: The cattle tick antigen, Bm95, expressed in Pichia pastoris contains short chains of N- and Oglycans. Arch. Biochem. Biophys. 432, 205-211 (2004)

33. Kamerling, J.P., Vliegenthart, J.F.G.: Carbohydrates. In: Lawson, A.M. (ed.) Clinical Biochemistry-Principles, Methods, Applications, Vol 1, Mass Spectrometry, pp. 175-263. Walter de Gruyter, Berlin, Germany (1989)

34. Packer, N.H., Lawson, M.A., Jardine, D.R., Redmond, J.W.: A general approach to desalting oligosaccharides released from glycoproteins. Glycoconj. J. 15, 737-747 (1988)

35. Thieme, T.R., Ballou, C.E.: Nature of the phosphodiester linkage of the phosphomannan from the yeast Kloeckera brevis. Biochemistry 10, 4121-4129 (1971)

36. Bigge, J.C., Patel, T.P., Bruce, J.A., Goulding, P.N., Charles, S. M., Parekh, R.B.: Nonselective and efficient fluorescent labeling of glycans using 2-aminobenzamide and anthranilic acid. Anal. Biochem. 230, 229-238 (1995)

37. Stroop, C.J.M., Weber, W., Gerwig, G.J., Nimtz, M., Kamerling, J.P., Vliegenthart, J.F.G.: Characterization of the carbohydrate chains of the secreted form of the human epidermal growth factor receptor. Glycobiology 10, 901-917 (2000)

38. Narui, T., Iwata, S., Takahashi, K., Shibata, S.: Partial hydrolysis of $\alpha$-D-glucans with acid in the presence of 1,1,3,3-tetramethylurea. Carbohydr. Res. 170, 269-273 (1987)

39. Guile, G.R., Rudd, P.M., Wing, D.R., Prime, S.B., Dwek, R.A.: A rapid high-resolution high-performance liquid chromatographic method for separating glycan mixtures and analyzing oligosaccharide profiles. Anal. Biochem. 240, 210-226 (1996)

40. Papac, D.I., Briggs, J.B., Chin, E.T., Jones, A.J.S.: A highthroughput microscale method to release $\mathrm{N}$-linked oligosaccharides from glycoproteins for matrix-assisted laser desorption/ ionization time-of-flight mass spectrometric analysis. Glycobiology 8, 445-454 (1998)

41. Vliegenthart, J.F.G., Dorland, L., van Halbeek, H.: High-resolution, ${ }^{1} \mathrm{H}$-nuclear magnetic resonance spectroscopy as a tool in the structural analysis of carbohydrates related to glycoproteins. Adv. Carbohydr. Chem. Biochem. 41, 209-374 (1983)

42. Hård, K., van Zadelhoff, G., Moonen, P., Kamerling, J.P., Vliegenthart, J.F.G.: The Asn-linked carbohydrate chains of human Tamm-Horsfall glycoprotein of one male. Novel sulfated and novel $\mathrm{N}$-acetylgalactosamine-containing $\mathrm{N}$-linked carbohydrate chains. Eur. J. Biochem. 209, 895-915 (1992)

43. Hernández, L.M., Ballou, L., Alvarado, E., Gillece-Castro, B.L.,
Burlingame, A.L., Ballou, C.E.: A new Saccharomyces cerevisiae mnn mutant N-linked oligosaccharide structure. J. Biol. Chem. 264, 11849-11856 (1989)

44. Koles, K., van Berkel, P.H.C., Pieper, F.R., Nuijens, J.H., Mannesse, M.L.M., Vliegenthart, J.F.G., Kamerling, J.P.: N- and O-glycans of recombinant human $\mathrm{C} 1$ inhibitor expressed in the milk of transgenic rabbits. Glycobiology 14, 51-64 (2004)

45. Michalski, J.-C., Haeuw, J.-F., Wieruszeski, J.-M., Montreuil, J., Strecker, G.: In vitro hydrolysis of oligomannosyl oligosaccharides by the lysosomal $\alpha$-D-mannosidases. Eur. J. Biochem. 189, 369-379 (1990)

46. Tseneklidou-Stoeter, D., Gerwig, G.J., Kamerling, J.P., Spindler, K.-D.: Characterization of N-linked carbohydrate chains of the crayfish, Astacus leptodactylus hemocyanin. Biol. Chem. HoppeSeyler 376, 531-537 (1995)

47. Byrd, J.C., Tarentino, A.L., Maley, F., Atkinson, P.H., Trimble, R. B.: Glycoprotein synthesis in yeast; identification of $\mathrm{Man}_{8-}$ $\mathrm{GlcNAc}_{2}$ as an essential intermediate in oligosaccharide processing. J. Biol. Chem. 257, 14657-14666 (1982)

48. De Waard, P., Kamerling, J.P., van Halbeek, H., Vliegenthart, J.F. G., Broertjes, J.S.S.: Characterization of N-linked gluco-oligomannose type of carbohydrate chains of glycoproteins from the ovary of the starfish Asterias rubens (L.). Eur. J. Biochem. 168, 679-685 (1987)

49. Trimble, R.B., Atkinson, P.H.: Structure of yeast external invertase $\mathrm{Man}_{8-14} \mathrm{GlcNAc}$ processing intermediates by 500megahertz ${ }^{1} \mathrm{H}$ NMR spectroscopy. J. Biol. Chem. 261, 98159824 (1986)

50. Cohen, R.E., Ballou, C.E.: Linkage and sequence analysis of mannose-rich glycoprotein core oligosaccharides by proton nuclear magnetic resonance spectroscopy. Biochemistry 19, 4345-4358 (1980)

51. Hardy, M.R., Townsend, R.R.: Separation of fucosylated oligosaccharides using high-pH anion-exchange chromatography with pulsed-amperometric detection. Carbohydr. Res. 188, 1-7 (1989)

52. Hernández, L.M., Ballou, L., Ballou, C.E.: Separation of yeast asparagine-linked oligosaccharides by high-performance anionexchange chromatography. Carbohydr. Res. 203, 1-11 (1990)

53. Hernández, L.M., Ballou, L., Alvarado, E., Tsai, P., Ballou, C.E.: Structure of the phosphorylated N-linked oligosaccharides from the mnn9 and mnn10 mutants of Saccharomyces cerevisiae. J. Biol. Chem. 264, 13648-13659 (1989)

54. Hernández, L.M., Olivero, I., Alvarado, E., Larriba, G.: Oligosaccharide structures of the major exoglucanase secreted by Saccharomyces cerevisiae. Biochemistry 31, 9823-9831 (1992)

55. De Waard, P., Vliegenthart, J.F.G., Kozutsumi, Y., Kawasaki, T., Yamashina, I.: Structural studies on phosphorylated oligosaccharides derived from yeast mannan by $1 \mathrm{H}(31 \mathrm{P})$ relayed spin-echo difference spectroscopy (RESED). J. Biol. Chem. 264, 1214112144 (1989)

56. Matzuk, M.M., Hsueh, A.J.W., Lapolt, P., Tsafriri, A., Keene, J.L., Boime, I.: The biological role of the carboxy-terminal extension of human chorionic gonadotropin $\beta$-subunit. Endocrinology 126, 376-383 (1990)

57. Sairam, M.R., Jiang, L.G.: Comparison of the biological and immunological properties of glycosylation deficient human chorionic gonadotropin variants produced by site directed mutagenesis and chemical deglycosylation. Mol. Cell. Endocrinol. 85, 227-235 (1992)

58. Erbel, P.J., Haseley, S.R., Kamerling, J.P., Vliegenthart, J.F.G.: Studies on the relevance of the glycan at Asn-52 of the $\alpha$-subunit of human chorionic gonadotropin in the $\alpha \beta$ dimer. Biochem. J. 364, 485-495 (2002) 